\title{
200 ka of glacial events in NW Svalbard: an emergence cycle facies model and regional correlations
}

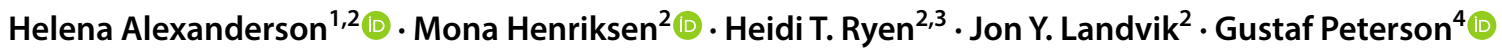

Received: 26 October 2017 / Accepted: 7 February 2018 / Published online: 16 February 2018

(c) The Author(s) 2018

\begin{abstract}
Late Quaternary sedimentary units at Kongsfjordhallet, NW Svalbard, represent five cycles of glaciations and subsequent deglaciations during high relative sea levels. The high sea level events are interpreted as glacioisostatically induced and imply preceding regional glaciations, which we constrain in time by luminescence and radiocarbon ages to just prior to $\sim 195$, $\sim 130, \sim 85, \sim 60$, and $\sim 15 \mathrm{ka}$. Combined with the stratigraphical record from nearby Leinstranda we identify six, possibly seven, major glacial advances during the last $200 \mathrm{ka}$ in the Kongsfjorden region. Two of these occurred during the Saalian and at least four during the Weichselian. The results are based on detailed sedimentological, stratigraphical and chronological investigations of the uppermost $15 \mathrm{~m}$ of the 40 -m-high Kongsfjordhallet coastal sections. The succession is dominated by sediments of marine and littoral origin, representing partial shallowing-upward sequences due to isostatic rebound. Only one subglacial till was recognised. Interestingly, alluvial and periglacial deposits, not commonly recognised in this type of setting, occur in the sequence. These include weathered coarse alluvium, sandy channel fills as well as cryoturbated sediments and solifluction deposits, which are positive evidence of a non-glacial environment. The sequence of sediments that represents an emergence cycle has been formalised in a facies model.
\end{abstract}

Keywords Quaternary · Glaciation · Sea level $\cdot$ Raised marine sediments · Facies model $\cdot$ Svalbard

Electronic supplementary material The online version of this article (https://doi.org/10.1007/s41063-018-0037-z) contains supplementary material, which is available to authorized users.

Helena Alexanderson

helena.alexanderson@geol.lu.se

Mona Henriksen

mona.henriksen@nmbu.no

Heidi T. Ryen

hry@nve.no

Jon Y. Landvik

jon.landvik@nmbu.no

Gustaf Peterson

Gustaf.Peterson@sgu.se

1 Department of Geology, Lund University, Sölvegatan 12, 22362 Lund, Sweden

2 Faculty of Environmental Sciences and Natural Resource Management, Norwegian University of Life Sciences, PO Box 5003 NMBU, 1430 Ås, Norway

3 Norwegian Water Resources and Energy Directorate, PO Box 5091, Majorstua, 0301 Oslo, Norway

4 Geological Survey of Sweden, Box 670, 75128 Uppsala, Sweden

\section{Introduction}

\section{Background}

The glacial and environmental development of Svalbard has been the subject of many studies during the last 30-40 years, which has increased our understanding of the Quaternary glacial history. While the Late Weichselian glacial extent, glacial dynamics and deglaciation in the Svalbard sector of the ice sheet are reasonably well known [1-3], large uncertainties remain for older glaciations [e.g. 2, 4-6]. This is partly due to a low preservation potential of older records that yields a bias towards representation of the younger events. Although the terrestrial record in Svalbard is fragmentary, it does provide evidence of multiple ice sheet expansion during the past ca $200 \mathrm{ka}$.

Several stratigraphic records contain glacial diamictons (tills) overlain by coarsening-upward sequences of marine mud to beach gravel. At some sites, two or three coarseningupward sequences can be found in direct succession [e.g. 7-9], each sequence interpreted to represent a glaciation with glacioisostatic down-warping succeeded by a deglaciation 
with marine deposition in deeper to gradually shallower water during crustal emergence [6,9-11]. As eustatic sea level was lower in the glacial periods [12], only regional glaciations have sufficient impact to explain a glacioisostatic uplift large enough for marine deposits to be found above present-day sea level $[6,13]$. High-sea-level events can, therefore, be used for correlation between sites along the west coast of Svalbard as the rigid crust is depressed over large areas by ice load $[6,13]$. Even when subglacial tills are lacking in the stratigraphic record, such high-sea-level events must represent major ice sheet advance and retreat allowing enough time for isostatically adjustments.

Glacioisostatic signals, or emergences cycles, have been used to identify and correlate glacial events in Svalbard for a long time [e.g. 6, 9]. However, as there are multiple events, absolute dating is necessary for exact correlation. The marine-to-littoral sediments, and associated fossils, are used for minimum age determination of the glacial events in the stratigraphic record by, e.g. luminescence and radiocarbon dating [13]. Despite the lack of tills and incomplete shallowing-upward sequences, correlations of stratigraphic units based on new chronology and better understanding of the depositional environment have recently led to an improved event stratigraphy as well as recognition of previously unknown glacial events [10, 14-16].

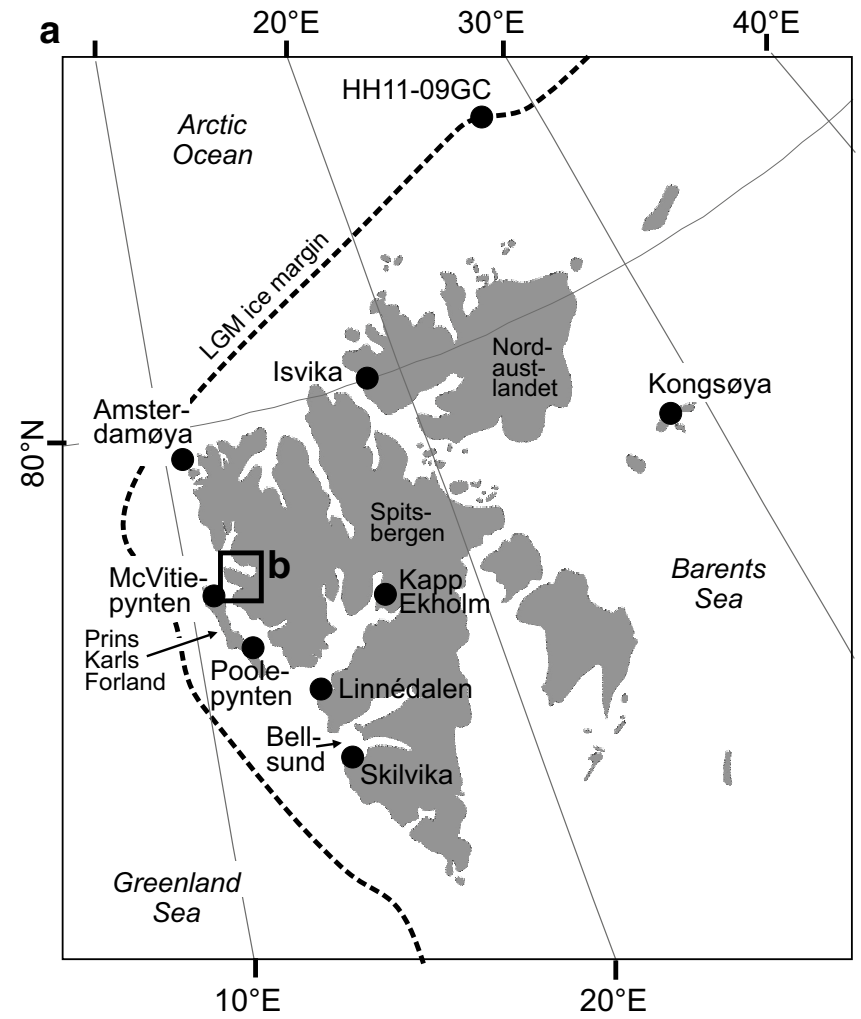

We present a new chronology and palaeoenvironmental interpretations from the Kongsfjordhallet successions in northwestern Svalbard. We have revised a formalised facies model of an emergence cycle from Alexanderson et al. [10] also to include terrestrial deposits, which are found at the study sites. Within the frame of the facies model the sedimentary records along Kongsfjorden have allowed us to recognise six, possibly seven, glacial events during the last $200 \mathrm{ka}$.

\section{Setting and previous work}

Kongsfjordhallet is located on the northern shore of Kongsfjorden on the west coast of Spitsbergen, Svalbard (Fig. 1). It is a ca $6-\mathrm{km}$-long and $1-2-\mathrm{km}$-wide gently sloping plain (130 to 30-40 $\mathrm{m}$ a.s.1.), ending in steep coastal cliffs. The local bedrock, which mainly consists of (garnet-)mica schist and some marble [17], is exposed along the lower parts of the coastal cliffs and in the larger, incised ravines. Most of the Kongsfjordhallet plain is covered by Quaternary sediments, mainly till and raised beach deposits [18]. Lateral moraines of Late Weichselian age are found on the plain, and large, neoglacial moraine complexes sit in front of valley glaciers protruding from the mountains to the NE [18-20].

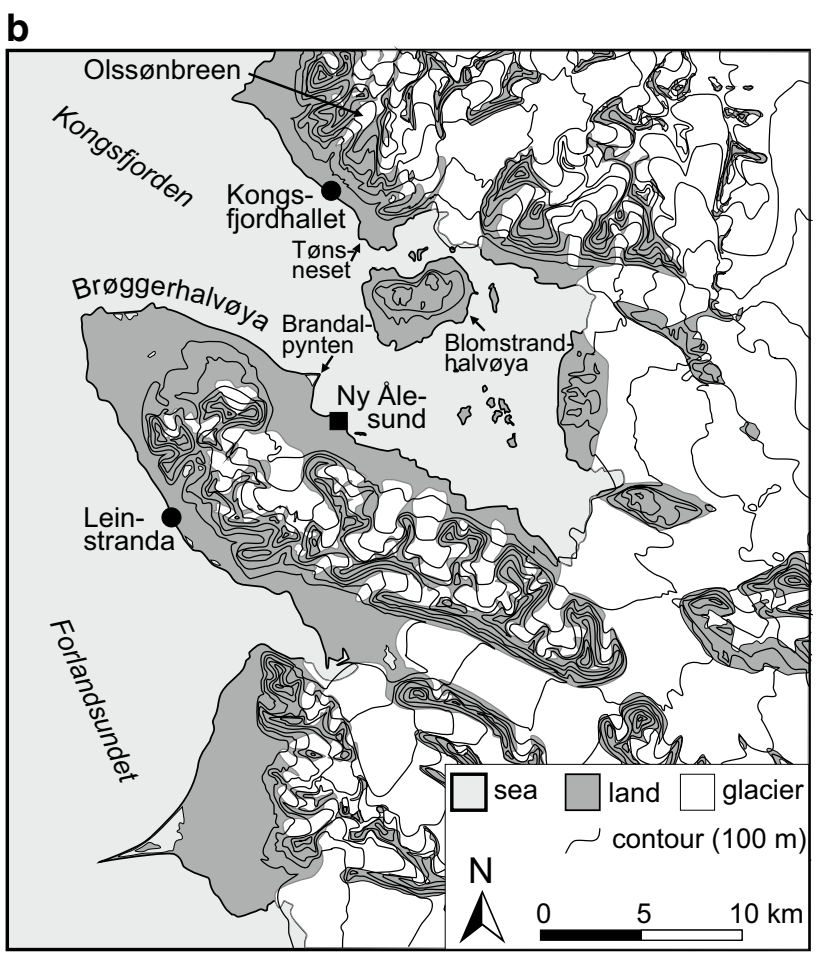

Fig. 1 Location maps. a Svalbard and key sites mentioned in the paper. b The Kongsfjorden area with the location of the sections at Kongsfjordhallet and other relevant places 
Along the coastal cliffs, more than $35 \mathrm{~m}$ of subhorizontal glacial, marine, littoral, alluvial and slope deposits are exposed [21, 22]. The sediments are dominated by glaciomarine diamictons and littoral gravels, and have previously been interpreted as three successions of glaciation, deglaciation and isostatic rebound [21,22]. The oldest succession (C) was suggested to be of Early Pleistocene age and the youngest (A) of Weichselian age by Houmark-Nielsen and Funder [22]. However, their chronology is based only on few data: two finite and five non-finite radiocarbon ages and two thermoluminescence ages from succession $\mathrm{A}$, and a palaeomagnetic record and mollusc fauna from succession $\mathrm{C}$.

In this study, we target the uppermost ca $15 \mathrm{~m}$ of the deposits, occurring along an 800-m-long stretch of the central part of the coastal sections of Kongsfjordhallet (Fig. 1b). These deposits are consistent with units 5 and 6 (succession A) of Houmark-Nielsen and Funder [22], and our studied sections approximately correspond to their Sects. 5, 6 and 8 (see their Figs. 2, 3).

\section{Glacial history of Kongsfjorden}

The Kongsfjorden area has been a key area for reconstructing the late Quaternary history of the Svalbard-Barents sea ice sheet [e.g. 9-11, 19-22, 24-27]. We summarise the current understanding of the environmental history of the Kongsfjorden area over the last $200 \mathrm{ka}$ based on these studies. Apart from scarce deposits of proposed early Quaternary age $[9,22]$, most records are interpreted to be from the last two glacial-interglacial cycles, and particularly from the Late Weichselian glaciation and the last deglaciation.

At least four regional glaciations preceding the Last Glacial Maximum (LGM) have been documented in the area, and each of them was followed by a high relative sea-level event $[10,11,22]$. The glaciations are dated at Leinstranda (Fig. 1b) to just prior to $185 \pm 8,129 \pm 10,99 \pm 8$, and $36 \pm 3 \mathrm{ka}[10,28]$. The sporadic preservation of pre-LGM stratigraphies and landforms indicates spatial variation in ice dynamics, from less active ice in inter-fjord areas to fastflowing ice in the fjords [2, 26]. Evidence of both regional (ice sheet) and local (e.g. valley) glaciers have been identified and reflects shifts in ice-sheet extent and dynamics [2, $10,19]$.

During the Late Weichselian, the Svalbard-Barents sea ice sheet reached the western shelf break around 23.6-22.6 cal. ka BP and deposited sediment in trough mouth fans [3, 27, 29-31] (Fig. 1). During the LGM, Kongsfjorden and its continuation westward across the continental
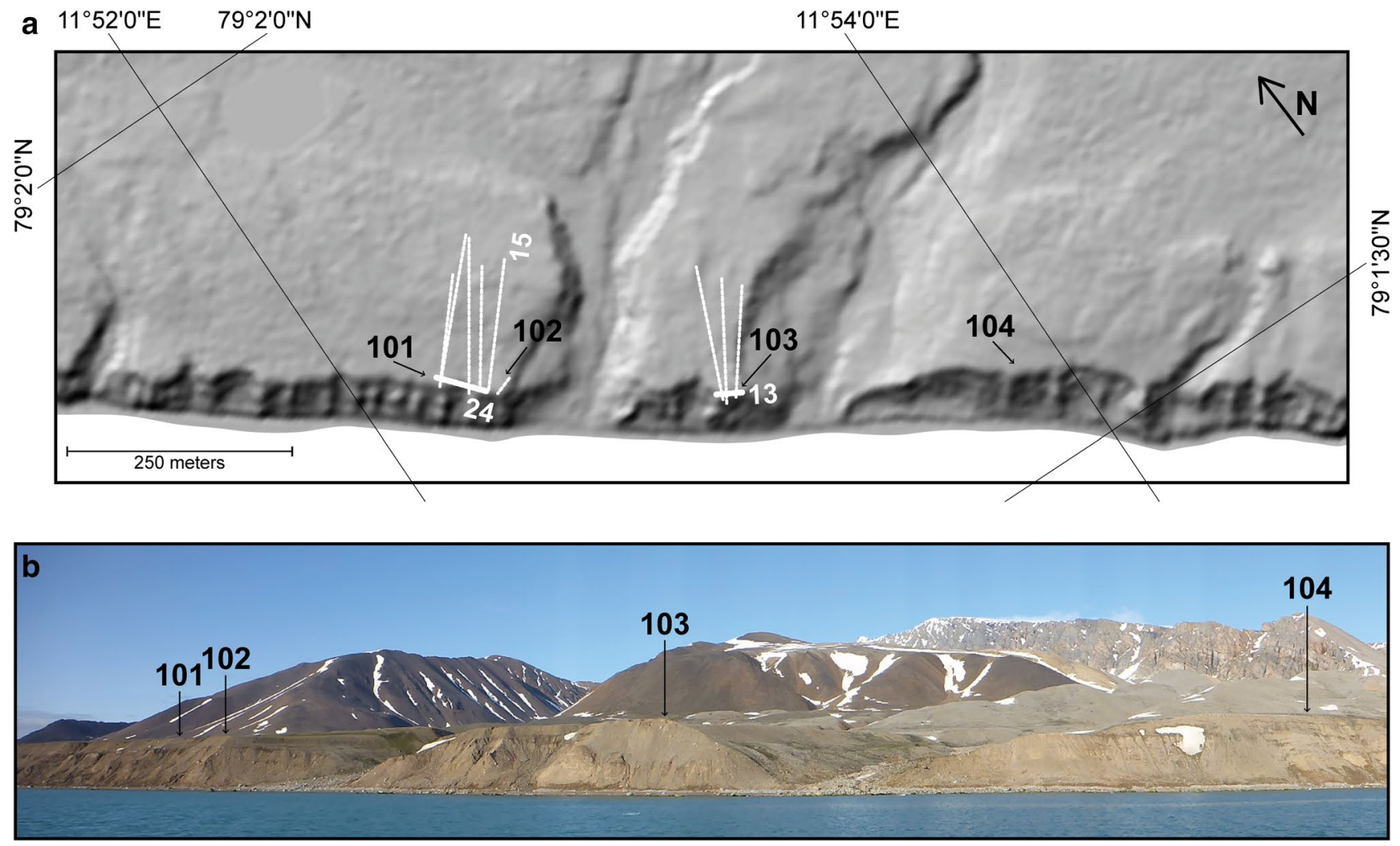

Fig. 2 Overview of the central part of Kongsfjordhallet. a Hillshade model of the Kongsfjordhallet plain and coastal cliffs with the location of the main sites: 101-104. GPR-profile locations are shown as white lines; the thicker lines are the profiles shown in Fig. 3. Digital terrain elevation data from NPI [23]. b View along the coastal cliffs 

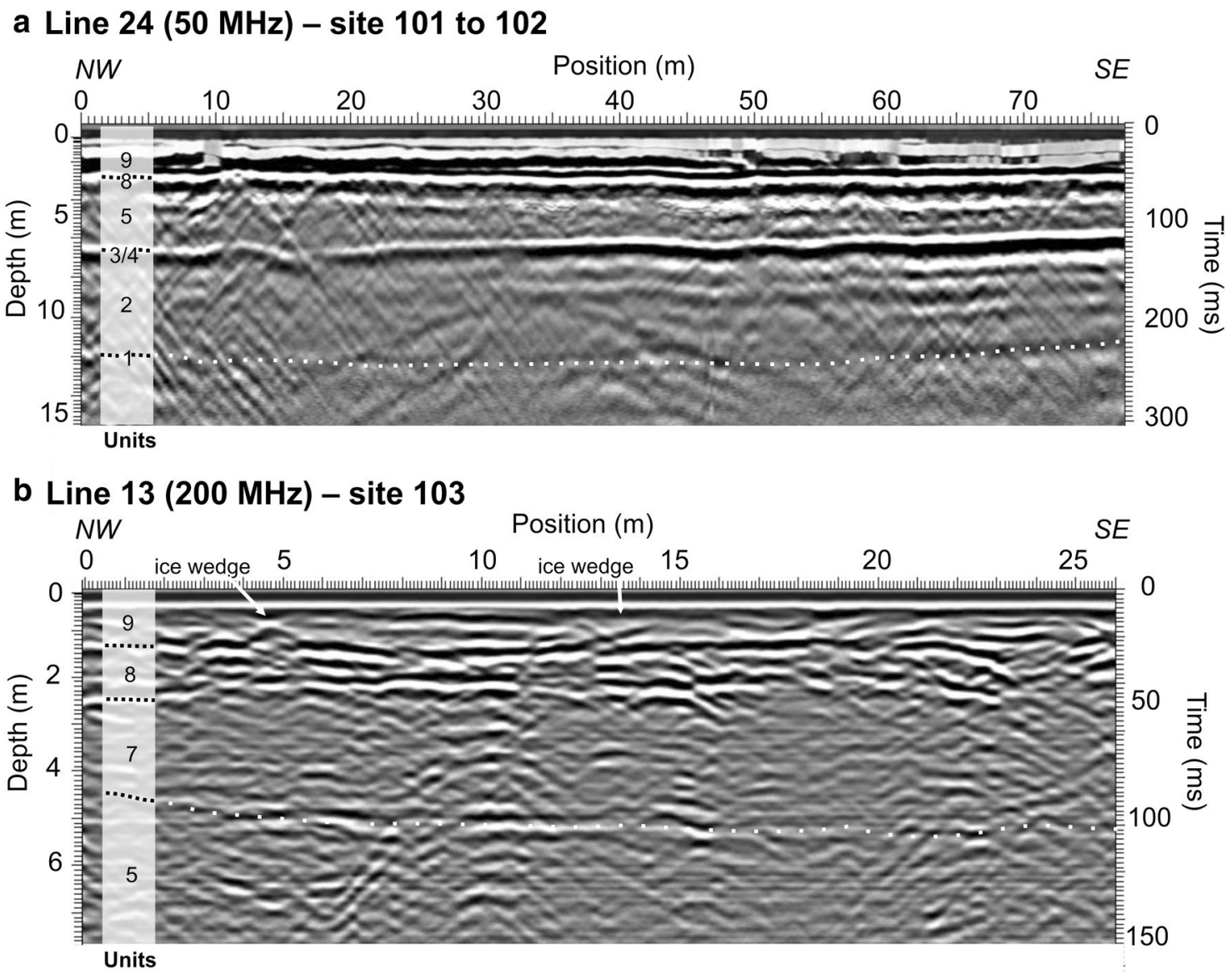

\section{Line $15(200 \mathrm{MHz})$ - coast to inland}

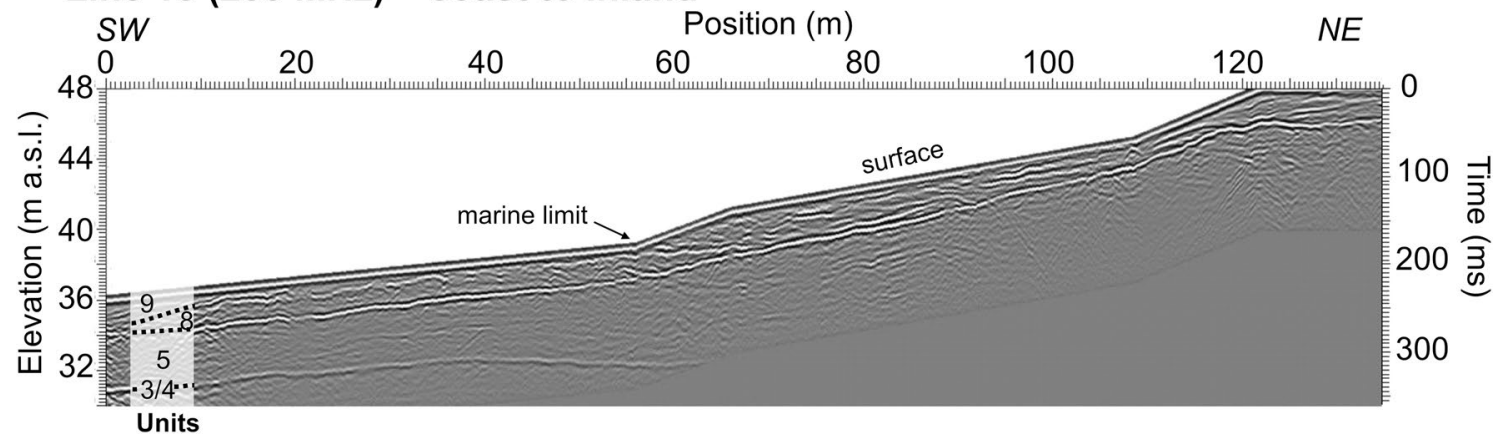

Fig. 3 Selected GPR profiles with interpretation. Note the different horizontal and vertical scales. For location of profiles, see Figs. 2a and 4 . a Coast-parallel profile line 24 showing the apparently horizontal architecture of the sediment units in the cliff at sites 101 and 102. The main reflectors are the marker bed units $1,3 / 4$ and 8 . b Coast-parallel profile line 13 showing the upper part of the stratigra-

shelf, the Kongsfjordsrenna trough, were occupied by a warm-based and fast-moving ice stream, as indicated by mega-scale glacial lineations (MSGL) on the sea floor [27], while ice in the interford areas probably was relatively inactive and left fewer traces [2, 25, 26].

Deglaciation at the shelf break is proposed to have started at ca 20.5 cal. ka BP $[1,32]$ and at $16.8-15.9$ cal. ka BP phy at site 103 . The very coarse subunit $7 \mathrm{a}$ is not distinguishable in the profile, but was mapped in the section. c Profile line 15 at right angles to the coast at site 102 . The main reflectors show that unit 8 rises parallel to the surface inland, while units $3 / 4$ appear to continue inland with a lower gradient, more horizontally

the ice margin had reached the mouth of Kongsfjorden [19, 26]. A westward ice flow in the Kongsfjorden basin is indicated by drumlins and glacial flutes on the sea floor [33]. The ice margin had retreated beyond Brandalpynten by 14.8-13.9 cal. ka BP [20] and in the Preboreal the ice margin was close to the location of the present glacier margins in the inner fjord [34]. 


\section{Materials and methods}

\section{Fieldwork}

Fieldwork at Kongsfjordhallet was carried out in the summers of 2007, 2008, 2009 and 2014. Brief visits were also made in 2011, 2012, 2013 and 2015. More than ten sites from Tønsneset in the SE to the stream from the Olssønbreen glacier in the NW were studied, but here we focus on the sedimentary successions at coastal cliff sites 101-104 (Fig. 2, Online Resources 1, 2). The upper part of the stratigraphy was targeted with sedimentological logging, fabric and palaeocurrent measurements and clast analyses. Clast roundness was determined on at least fifty $2-8 \mathrm{~cm}$ clasts and using the comparison chart of Krumbein [35] and the categories of Powers [36]. Ground-penetrating radar (GPR) investigations were carried out with a Sensors \& Software pulseEKKO 100 radar $(400 \mathrm{~V})$ with antenna frequencies of 50 and $200 \mathrm{MHz}$. Post-processing of GPR-data was done in EKKO_View and EKKO_View Deluxe (Sensors \& Software, Inc.). Profiles along the coast (Figs. 2, 3a, b) were not topographically corrected since the surface within the range of each profile is fairly horizontal. For profiles perpendicular to the coast (Figs. 2, $3 c$ ), a simple topographic correction was done based on point measurements at start, stop and changes of slope along the profiles by the use of barometric altimeter in a handheld Garmin eTrex Vista HCx GPS. Prominent GPR reflectors were correlated to lithostratigraphic units visible in cleaned sections and the marker beds were also followed laterally along the cliffs. Sampling for optically stimulated luminescence (OSL), electron spin resonance (ESR) and radiocarbon $\left({ }^{14} \mathrm{C}\right)$ dating was made.

\section{Chronology}

The procedures for optically stimulated luminescence (OSL) and electron spin resonance (ESR) dating are described in detail in Alexanderson et al. [28]. The OSL ages are based on large $(8 \mathrm{~mm})$, single aliquots of 180-250 $\mu \mathrm{m}$ quartz grains, analysed with post-IR blue SAR-protocols [37] in Ris $\varnothing$ TL/OSL readers. Measurements were carried out at the Nordic Laboratory for Luminescence Dating (NLL), Aarhus University in Denmark (samples from 2007 to 2009) and at the Lund Luminescence Laboratory, Lund University (samples from 2014). Dose rates were determined by high-resolution gamma spectrometry [38] and by calculating the contribution of cosmic rays according to Prescott and Hutton [39]. Water content at the time of sampling and at saturation were measured using cylinder volumeters [40] and the average water content since time of deposition was estimated to be close to saturation for most of the time [28]. The three OSL samples from unit 5 and two of the samples from unit 2 (R-081350/51) contained aliquots that had equivalent doses $\left(D_{\mathrm{e}}\right)$ close to saturation $\left(>2 \mathrm{D}_{0}\right.$; Wintle and Murray [41]). As rejection of these aliquots may bias the dose distribution [42], they were accepted if a dose could be calculated.

The ESR ages were determined from selected marine mollusc shells (Hiatella arctica, Mya truncata, Astarte sp.). The analyses were done at the Research Laboratory for Quaternary Geochronology at Tallinn University of Technology in Estonia according to procedures in Molodkov [43, 44].

One sample (seal bone) was dated at the Radiocarbon Dating Laboratory at Lund University. The age was calibrated using $\mathrm{OxCal} 4.2$ online [45] with the Marine 13 calibration curve [46] and assuming $\Delta R=20 \pm 30$ a [47]. Previously published radiocarbon ages were recalibrated in the same way and all radiocarbon ages are presented as two-sigma age ranges.

\section{Results}

\section{Sediment architecture}

We have divided the studied Kongsfjordhallet deposits into ten stratigraphic units, labelled 1-10 (Fig. 4). Of these, the finer grained units 1, 3/4 and 8 can be mapped as marker horizons separating dominantly gravelly sediments. The gently undulating marker units are traceable for several hundreds of metres, both visually - as moist horizons and/or as prominent, erosion-resistant steps in slope-and in GPR profiles (Figs. 3, 4). The GPR reflector of the geophysically indistinguishable units 3/4 weakens in some places where these layers thin to a few decimetre thicknesses. Towards the inland, unit 8 is parallel with the gently rising surface, whereas the lower units $3 / 4$ are subhorizontal (Fig. 3c). In general, the studied part of the Kongsfjordhallet section consists of continuous, parallel and relatively horizontal layers, gently dipping towards the fjord. It should, however, be noted that despite that the sediments located between units 4 and 9 in the upper part of the stratigraphy are lithologically similar along the investigated part of the cliffs, they do have different ages at sites 101-102 and 103-104, respectively (units 5-6, 8; Fig. 4, Online Resource 2), which leads to a laterally differentiated stratigraphy (discussed further below). Units 10 and 7 are also exceptions to the general pancake stratigraphy; unit 10 only occurs in section 104 and unit 7 fills a half-channel form in section 103 . 


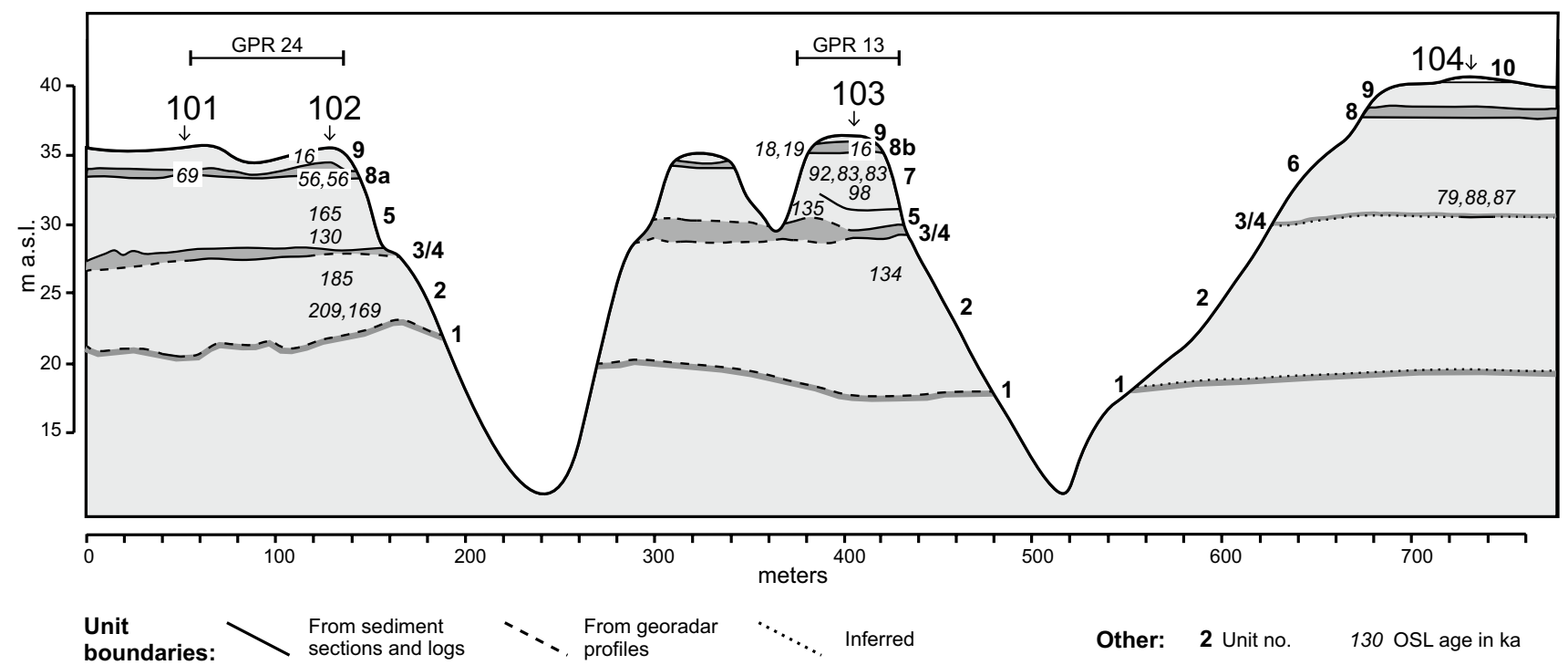

Fig. 4 Vertically exaggerated section view along the coastal cliffs with unit boundaries and OSL ages. Marker beds (units $1,3 / 4$ and 8) are shaded in darker grey. Locations of the GPR profiles in Fig. 3a, b are also shown

\section{Sediment units}

\section{Unit 1: glacimarine diamicton}

Unit 1 is a $>0.4-m$-thick brown silty, massive matrix-supported diamicton that contains fragments of mollusc shells (Fig. 5). Its lower boundary is sharp towards sandy gravel. Clasts are angular to sub-rounded, some are striated. Clast orientation shows no preference (girdle fabric; Fig. 5). The unit has been documented in detail at site 101, but is also present at other sites along the coast (Fig. 4).

The unit is interpreted as glacimarine in origin, mainly based on the grain size, the shell fragments and the weak clast fabric. The clasts are likely ice-rafted drop stones, deposited distal to a tidewater glacier. The girdle fabric suggests that clasts could fall over when dropped, indicating either a very soft or compact sediment [48, 49].

\section{Unit 2: marine sand and gravel}

Unit 2 consists of beds of alternating sandy and gravelly lithofacies (Fig. 5). Bed boundaries are typically sharp, but for some of the coarse-to-fine transitions, the boundaries are gradual. The fine-medium sand beds are laminated or massive and contain unpaired shells and shell fragments (Fig. 5), and paired shells in living position at some sites. Scattered clasts, some of which are quartzite, occur. Down-warped laminae were observed beneath some clasts.

The coarser subunits consist of normally graded massive beds of clast-supported (cobbly) gravel or matrix-supported sandy gravel. Imbrication was observed at the base of a few beds. Shell fragments, and some whole single shells, occur in the mid- and upper part of the unit, and they increase in size toward the top. The maximum particle size (MPS) in most beds is $25 \mathrm{~cm}$, but there are also a few boulders of 0.5-1 $\mathrm{m}$ size. Gneiss and quartzite clasts are common.

In total, the unit is $\sim 5 \mathrm{~m}$ thick, with individual sand beds $\sim 0.2 \mathrm{~m}$ in thickness, and gravelly beds $\sim 0.5-1 \mathrm{~m}$ thick. Both gravelly and sandy beds dip $\sim 10^{\circ}$ to the NW. The unit has been documented at sites 101, 102 and 103 and thus has a lateral extent of $>350 \mathrm{~m}$ (Fig. 4). It was dated by OSL to 209-134 ka (mean $172 \pm 13 \mathrm{ka} ; n=4$, Table 2 ) and by ESR to $79-41 \mathrm{ka}(n=5$, Table 3$)$.

These beds are interpreted to represent repeated concentrated density flows [50] in a shallow marine environment, likely on one or more subaquatic fans. The coarse material shows that the sediment source is relatively close. The normally graded gravelly beds correspond to facies $\mathrm{R}_{3}$ of the Lowe sequence [51], and the imbricated clasts at the base of some beds imply transport by traction (facies $\mathrm{R}_{1}$ ). The sandy beds were likely deposited during a later, sand-dominated turbulent phase, and represent mainly Lowe sequence facies $S_{1}$ and $S_{2}$ [51]. There was sufficient time between most flow events to allow benthic fauna to establish. Dropstones, indicated by the deformed laminae [52], imply calving glaciers or fjord ice in the area.

\section{Unit 3: glacial diamicton}

Unit 3 is a compact, massive matrix-supported silty diamicton, $\sim 0.5 \mathrm{~m}$ thick (Fig. 6). It exhibits fissility and is in places underlain by sheared sediments. Small shell fragments occur, particularly towards the base. The unit has a lateral extent of at least $350 \mathrm{~m}$ and has been mapped at sites 101, 


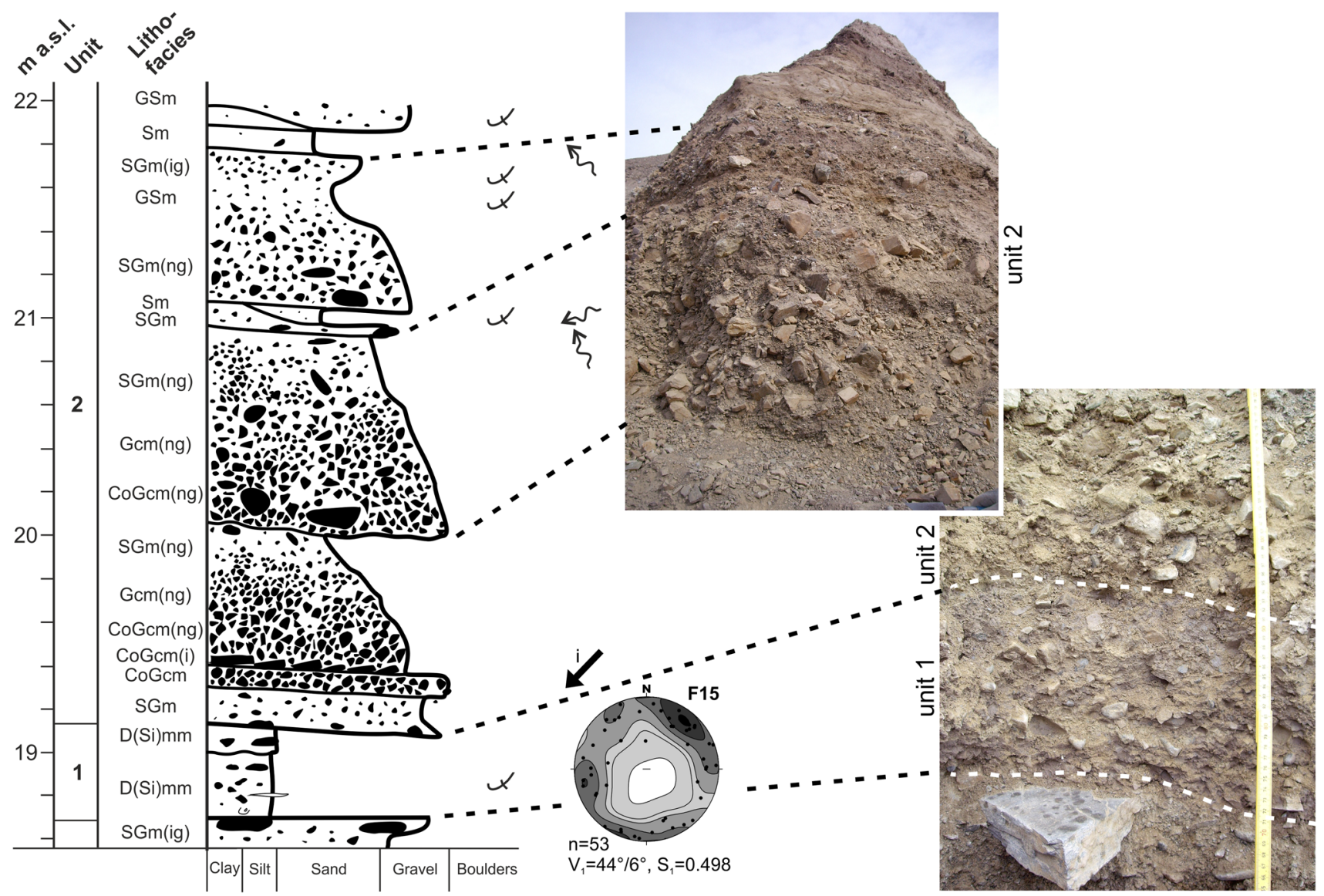

\section{Log symbols}

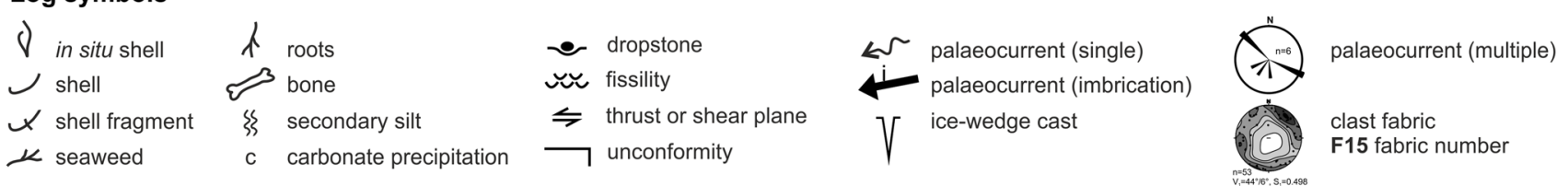

Fig. 5 Units 1 and 2 at site 101. The white, hatched lines in the photo represent unit boundaries. For explanation of lithofacies codes, see Table 1

102 and 103 (Fig. 4). The unit's lower contact and the underlying deformation structures are tilted towards $\mathrm{N}$ (strike/dip: $095^{\circ} / 18^{\circ} \mathrm{N}$ ) at site 101 . In parts of the sections, especially in the SE, the unit is represented only by a horizon with several flat-topped crystalline boulders, some of them bullet shaped (Fig. 6c). The flat boulder surfaces are mostly smooth, but one boulder carried a few striae with orientations $012^{\circ}-192^{\circ}$ and $072^{\circ}-252^{\circ}$. At other places the unit is represented by a horizon or 30-40-cm-long lenses of abundant clasts in a silty sandy matrix, commonly having a reddish colour. Many of these large clasts are crystalline. Small clasts show no or weakly preferred orientation (Figs. 6b, 7). A single shell (Mya truncata) and a shell fragment (Hiatella arctica) have been dated by ESR to $72-64 \mathrm{ka}(n=2$, Table 3$)$.

The diamicton is interpreted as a subglacial traction till [53], mainly based on its large lateral extent, its fissility, compactness and the underlying deformed beds. The smooth and abraded boulder surfaces are likely a result of subglacial erosion of clasts anchored in the substrate [e.g. 54, 55]. The direction of deformation and the few striae suggest that ice moved from the NNE (i.e. local glaciers; cf. Fig. 1), whereas the crystalline clasts and the reddish sediments have a provenance to the east, where Devonian red sandstones and crystalline basement rocks crop out [56], i.e. suggesting regional ice movement. The fabrics from site 103 are weak (girdle shape); this may be due to locally sandier matrix or closeness to larger boulders, and are largely inconclusive when it comes to reconstructing ice-movement direction, and overall provides little genetic information here.

Houmark-Nielsen and Funder [22] recognised a subglacial till within their succession A, which may correlate with our unit 3 . They interpreted it as having been deposited by a 
Table 1 Lithofacies codes used in sediment logs and sketches

\begin{tabular}{llll}
\hline Grain size & & Texture and structure \\
\hline $\mathrm{D}$ (Si, C, etc.) & $\begin{array}{l}\text { Diamicton, } \\
\text { silty, clayey, } \\
\text { etc. }\end{array}$ & $\mathrm{m}$ & Massive \\
$\mathrm{CoG}$ & Cobbly gravel & $\mathrm{ms}$ & Matrix-supported, stratified \\
$\mathrm{G}$ & Gravel & $\mathrm{mm}$ & Matrix-supported, massive \\
$\mathrm{SG}$ & Sandy gravel & $\mathrm{cm}$ & Clast-supported, massive \\
$\mathrm{GS}$ & Gravelly sand & $\mathrm{cs}$ & Clast-supported, stratified \\
$\mathrm{S}$ & Sand & tc & Trough-cross-stratified \\
$\mathrm{SiS}$ & Silty sand & $\mathrm{r}$ & Ripple laminated \\
$\mathrm{SSi}$ & Sandy silt & 1 & Laminated \\
$\mathrm{Si}$ & Silt & (dr) & Draped \\
$\mathrm{CSi}$ & Clayey silt & (ng) & Normally graded \\
$\mathrm{SiC}$ & Silty clay & (ig) & Inversely graded \\
$\mathrm{C}$ & Clay & (bi) & Bimodal \\
& & (o) & Open framework \\
& & (i) & Imbricated \\
& & (k) & Compact \\
\hline
\end{tabular}

glacier moving towards the NW based on fabric analyses at sites further south than those investigated here.

\section{Unit 4: glacimarine mud}

Unit 4 is a clayey, silty massive diamicton that ranges in thickness from a few dm up to $1.5 \mathrm{~m}$ (Figs. 6, 8). It contains shell fragments and occasional whole shells, as well as gravel clasts $(<15 \mathrm{~cm})$ scattered throughout the unit. A clast-rich horizon occurs in the lower part. Some light-coloured silty laminae occur close to the base of the unit, and some of these lamina were bending below clasts (Fig. 8). The unit has been documented at sites 101-104 and can be traced at least $90 \mathrm{~m}$ inland by GPR (Figs. 3c, 4). A fragmented Hiatella arctica shell has been dated by ESR to 66-45 ka $(n=1$, Table 3$)$.

The deformed lamina beneath the clasts suggest that the clasts are dropstones [52], and the lamina likely represent individual turbidites. The unit is interpreted as glacimarine mud with IRD, a dropstone mud in the terminology of Powell [57].

\section{Unit 5: littoral sand and gravel}

Unit 5 consists of two interfingering subunits: $5 \mathrm{a}$, which dominates in the lower part, and 5b in the upper part (Fig. 9). Subunit $5 \mathrm{a}$ is stratified with massive gravelly sand or massive sand containing some shell fragments. The lower boundary is sharp. Beds are $\sim 10 \mathrm{~cm}$ in thickness and bed sets $40-80 \mathrm{~cm}$ thick. Subunit $5 \mathrm{~b}$ is also stratified, but coarser and is made up of alternating beds of sandy gravel and gravelly sand. The beds are massive; many are normally graded, most of the gravel beds also clast-supported. Individual beds are $\sim 20 \mathrm{~cm}$ in thickness. Clasts up to $7-20 \mathrm{~cm}$ occur, but most are $0.5-1.5 \mathrm{~cm}$ and are subrounded to rounded. A few shell fragments have been found. The beds dip $6-12^{\circ}$ towards SW at site 102 and the total unit thickness is $\sim 3 \mathrm{~m}$ (Fig. 9). Similar gentle dip of internal structures is also seen in GPR profiles (Fig. 3c). The unit has been observed from site 101 to site 103 , where it wedges out and is laterally replaced by unit 7 (Fig. 4). It thus has a lateral extent of $>350 \mathrm{~m}$, and according to GPR profiles it may be traced at least $150 \mathrm{~m}$ inland, where it also reaches an elevation of ca $45 \mathrm{~m}$ a.s.l. (Fig. 3c). The sand beds have been dated by OSL to $165-130 \mathrm{ka}$ (mean $139 \pm 7 \mathrm{ka} ; n=3$, Table 2).

The interfingering shows that the two subunits represent a transition between two co-existing depositional environments. The sediments are interpreted as littoral, supported by their large lateral extent, and the gradual change from a lower energy to a higher energy environment as caused by shallowing. This shallowing is most likely due to land uplift, and since the unit continues inland, the sediments exposed in the coastal section are probably part of a (once) extensive body of beach sediments deposited at successively lower elevations during regression. This coarsening-upward unit thus represents a shallowing-upward succession, with the sand interpreted as shoreface sand and the gravelly beds as beachface gravel [58].

\section{Unit 6: littoral sand and gravel}

Unit 6 consists of two subunits, both of which have only been observed at site 104 and the lateral extent is, therefore, uncertain (Fig. 4). The sandy subunit $6 \mathrm{a}$ and the gravelly subunit $6 \mathrm{~b}$ are similar to their counterparts in unit 5 (see "Unit 5: littoral sand and gravel"), though the gravelly facies (subunit 6b) dominates here (Fig. 10). The stratified gravelly sand of subunit $6 \mathrm{a}$ forms $\mathrm{dm}$-thick beds with either gradational or sharp boundaries to the gravel. Subunit $6 \mathrm{~b}$ consists of massive or vaguely stratified sandy gravel, which in places is graded and may contain larger clasts $(<25 \mathrm{~cm})$. The beds dip $2-3^{\circ}$ towards the S-SW. Mats of sea weed, a few $\mathrm{cm}$ thick, are incorporated in the gravel (Fig. 11). Subunit $6 \mathrm{a}$ has been OSL dated to $88-79 \mathrm{ka}$ (mean $83 \pm 4 \mathrm{ka}$; $n=3$, Table 2; Fig. 10).

Similar to unit 5 , unit 6 is interpreted as a shallowing-upward sequence, from a shoreface to beachface environment.

\section{Unit 7: alluvial gravel}

Unit 7 is divided into two subunits, the coarser subunit $7 \mathrm{a}$ and the finer subunit $7 \mathrm{~b}$, both observed at site 103 directly overlying unit 5 (Fig. 4). Subunit $7 \mathrm{a}$ is at most $2 \mathrm{~m}$ thick 


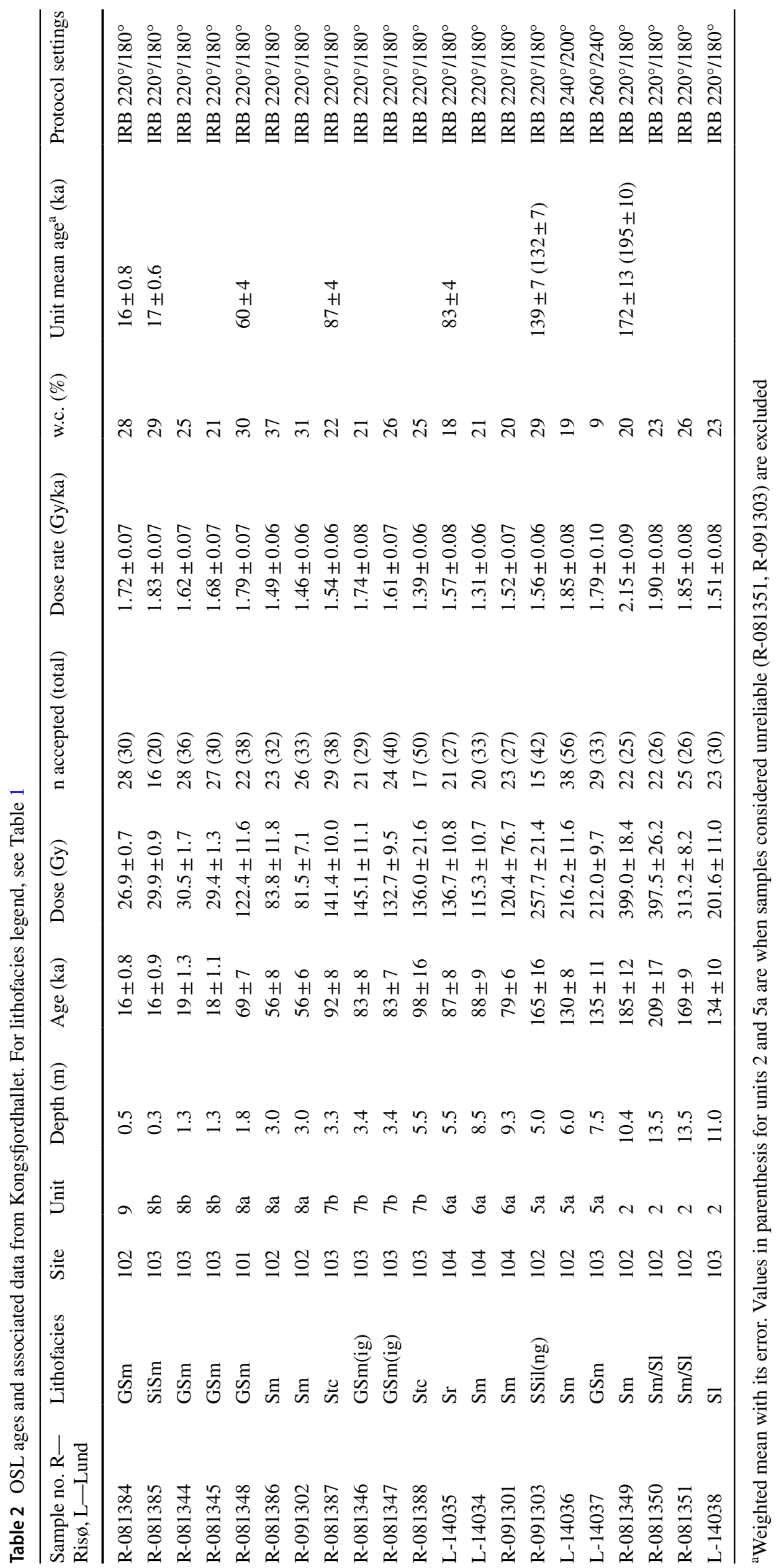


Table 3 ESR ages and associated data from Kongsfjordhallet

\begin{tabular}{|c|c|c|c|c|c|c|c|c|c|c|}
\hline Sample no. RLQG & Species & Site & Unit & Depth (m) & $\operatorname{Age}^{a}(\mathrm{ka})$ & Dose (Gy) & $U_{\text {in }}(\mathrm{ppm})$ & $U_{\text {sed }}(\mathrm{ppm})$ & $\mathrm{Th}_{\text {sed }}(\mathrm{ppm})$ & $\mathrm{K}_{\text {sed }}(\%)$ \\
\hline $385-039$ & Hiatella arctica $(f)$ & 101 & 4 & 8.3 & $66-45$ & 165 & 6.64 & 2.24 & 9.27 & 2.70 \\
\hline $386-039$ & Hiatella arctica $(f)$ & 101 & 3 & 9.2 & $64 \pm 5$ & 153 & 0.90 & 2.19 & 8.78 & 2.57 \\
\hline $390-039$ & Mya truncata & 101 & 3 & 9.6 & $72 \pm 5$ & 168 & 0.81 & 2.01 & 8.74 & 2.25 \\
\hline 391-039 & Hiatella arctica & 102 & 2 & 12.5 & $77-47$ & 145 & 7.20 & 1.17 & 5.15 & 1.58 \\
\hline $392-039$ & Hiatella arctica & 102 & 2 & 12.5 & $74-42$ & 136 & 8.50 & 1.17 & 5.15 & 1.58 \\
\hline $387-039$ & Hiatella arctica & 102 & 2 & 14.3 & $75-58$ & 142 & 3.60 & 1.48 & 5.23 & 1.67 \\
\hline $388-039$ & Hiatella arctica & 102 & 2 & 14.3 & $73-57$ & 138 & 3.26 & 1.53 & 5.44 & 1.66 \\
\hline 389-039 & Hiatella arctica $(p)$ & 102 & 2 & 14.3 & $79-54$ & 146 & 5.05 & 1.53 & 5.44 & 1.66 \\
\hline
\end{tabular}

$f$ fragment, $p$ paired shell

${ }^{a}$ Where a range is given, the younger age is calculated with the measured $U_{\text {in }}$, which is unusually high, while the older age is calculated with a standard $U_{\text {in }}=0.80 \mathrm{ppm}$. See discussion in Alexanderson et al. [28]

Fig. 6 a $\log$ of units 2, 3 and 4 at site 101. See Fig. 5 and Table 1 for legend. b Fabric in unit 3 at site 103, see Online Resource 2 for location. c Some of the large clasts with smooth upper surfaces that replace unit 3 laterally (here site 103)
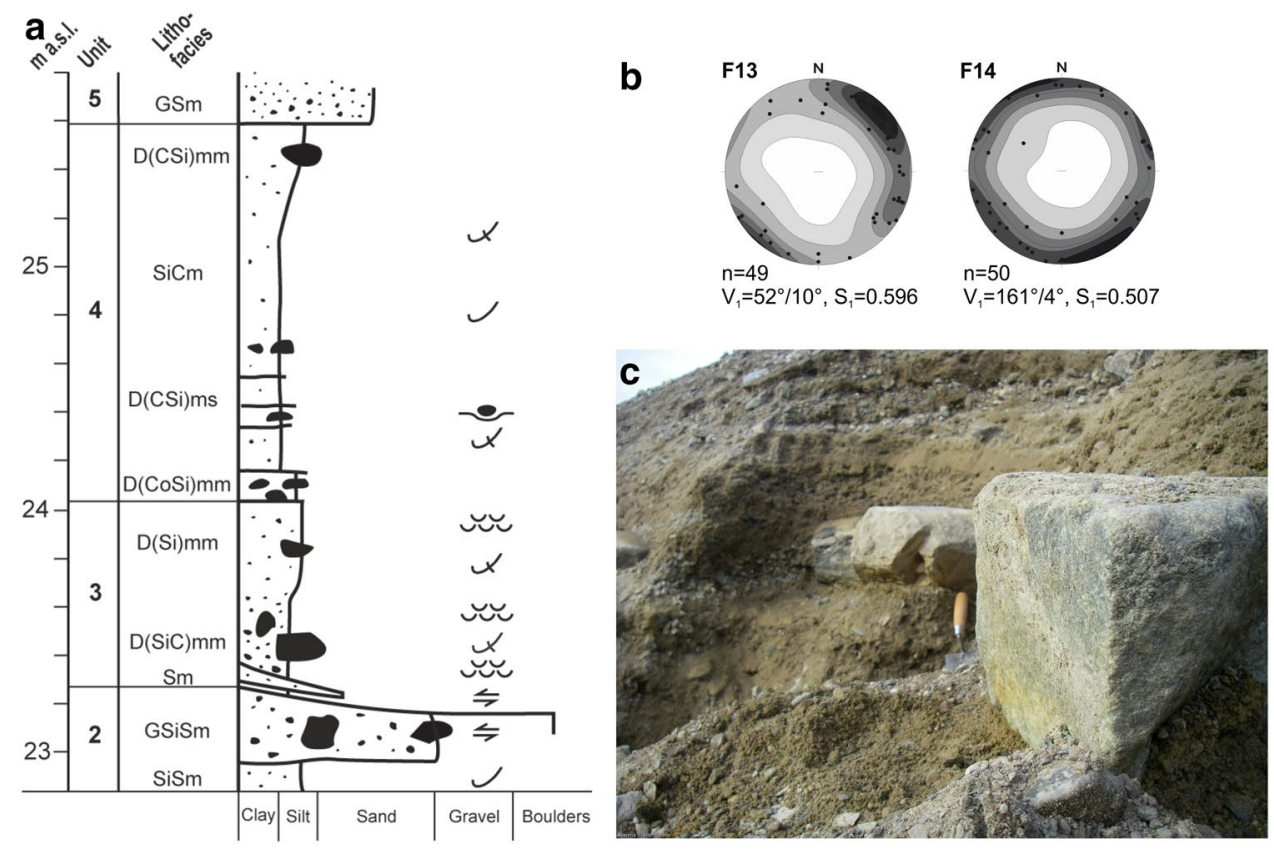

and wedges out towards the NW. It is poorly sorted, clastsupported, massive cobbly gravel with a fine-medium sand matrix. Clasts are up to $25 \mathrm{~cm}$ in size, and the larger clasts, including some rounded gneiss clasts (Fig. 12a), are more frequent along the base. Most clasts, particularly those of carbonate rocks (mainly marble), are shattered into small pieces, but still retain their original shape (Fig. 12b). This is particularly apparent in the uppermost part of the subunit.

Subunit $7 \mathrm{~b}$ is stratified but heterogeneous. It is made up of beds of massive or trough-cross-stratified gravelly sand or sandy gravel, massive clast-supported gravel and cobbly gravel, in places separated by decimetre-thick beds of laminated medium to coarse sand (Fig. 13). The coarser beds have erosive lower boundaries and some rip-up clasts have been observed. Clasts are mainly subrounded and the MPS is $\sim 20 \mathrm{~cm}$; some clasts are also shattered and have carbonate precipitates [cf. 59] on their undersides. In places, clasts are imbricated, with a general dip towards the NE (Fig. 13). A sandy wedge cuts through part of the subunit, and in the upper part of the subunit there are undulating deformations (Fig. 13). Like subunit 7a, subunit $7 \mathrm{~b}$ also wedges out towards the NW, but its exact lateral extent in that direction could not be determined due to scree cover and the steepness of the slopes. In GPR profiles, unit 7 is dipping gently towards the fjord and can be traced at least $60 \mathrm{~m}$ inland. Subunit $7 \mathrm{~b}$ is OSL dated to $98-83 \mathrm{ka}$ (mean $87 \pm 4 \mathrm{ka} ; n=4$; Table 2).

The sedimentary structures, the lack of fine material and the overall wedge- or trough-shaped architecture suggest that the sediments in subunits $7 \mathrm{a}$ and $7 \mathrm{~b}$ were deposited as bars and channels in a fluvial environment, possibly within a ravine or a small valley. The unit is located next to the 


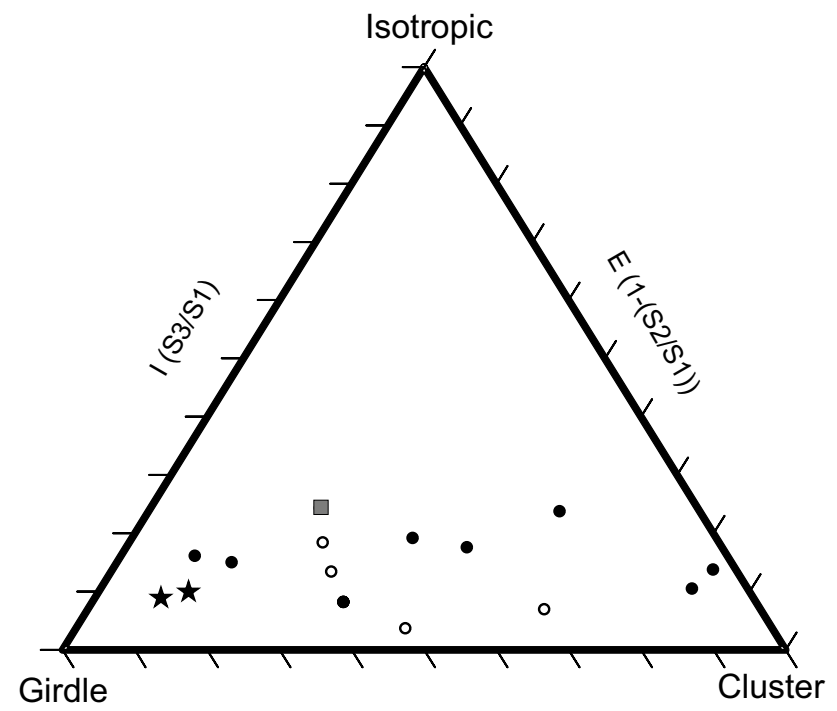

$\square$ unit $1 \star$ unit $3 \quad \circ$ subunit $8 \mathrm{a} \quad$ subunit $8 \mathrm{~b}$

Fig. 7 Summary plot of fabric shape for units 1, 3 and 8. See Figs. 5, $6 \mathrm{~b}$ and Online Resource 3 for plots of individual data sets

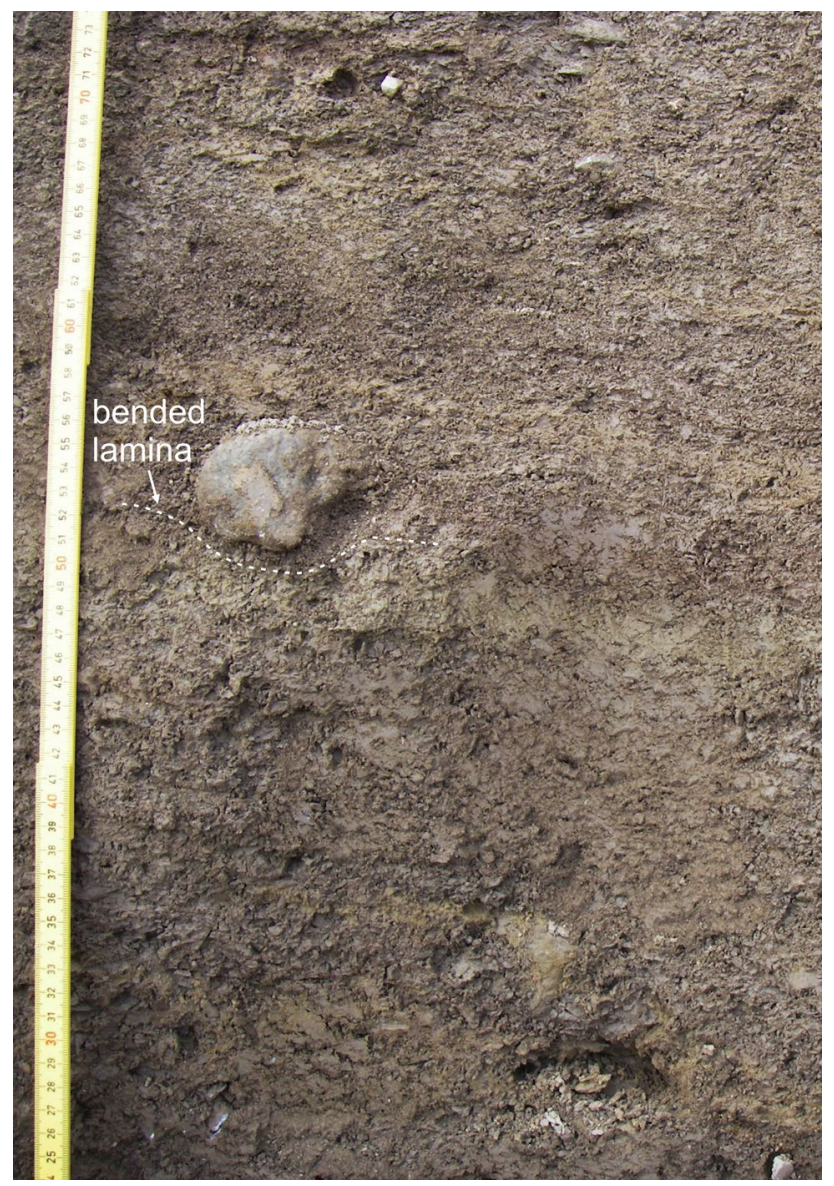

Fig. 8 Glacimarine mud with dropstones in the lower part of unit 4 at site 101

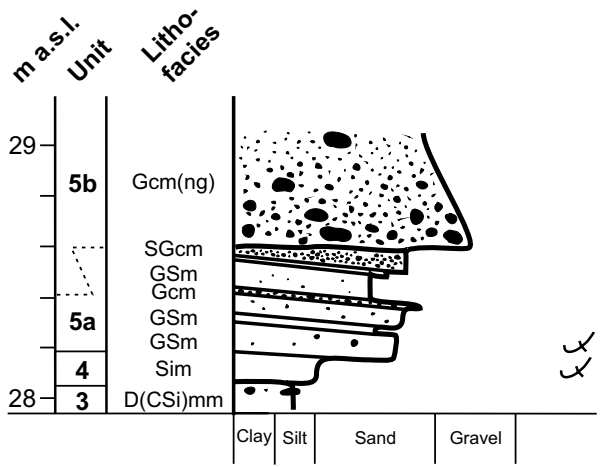

Fig. 9 Unit 5 overlying units 4 and 3 at site 102. The sandy subunit $5 \mathrm{a}$ interfingers with and is successively replaced by the gravelly subunit 5b. See Fig. 5 and Table 1 for legend

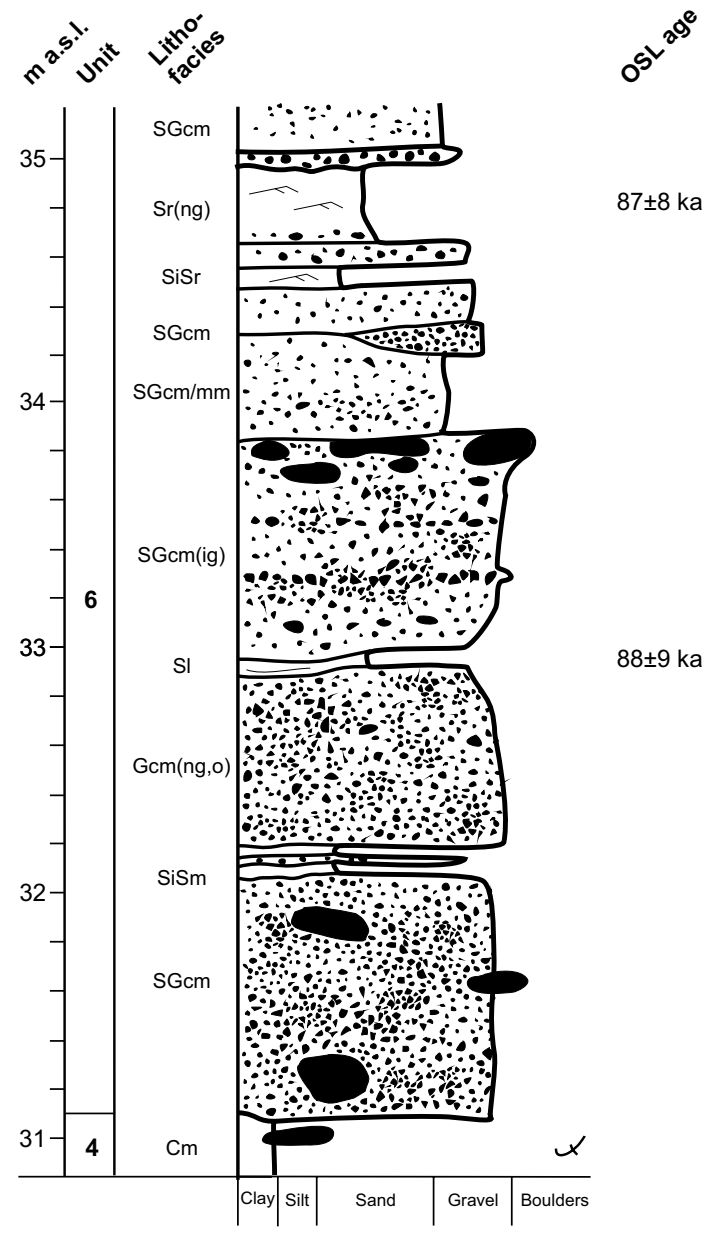

Fig. 10 Units 4 and 6 at site 104. The sandy subunit $6 a$ alternates (interfingers) with the gravelly subunit 6b. See Fig. 5 and Table 1 for legend

present-day ravine (Fig. 4) and since the course of the ravine is partly bedrock-controlled in its upper part, it is likely that earlier streams may have followed a similar path. The NW 


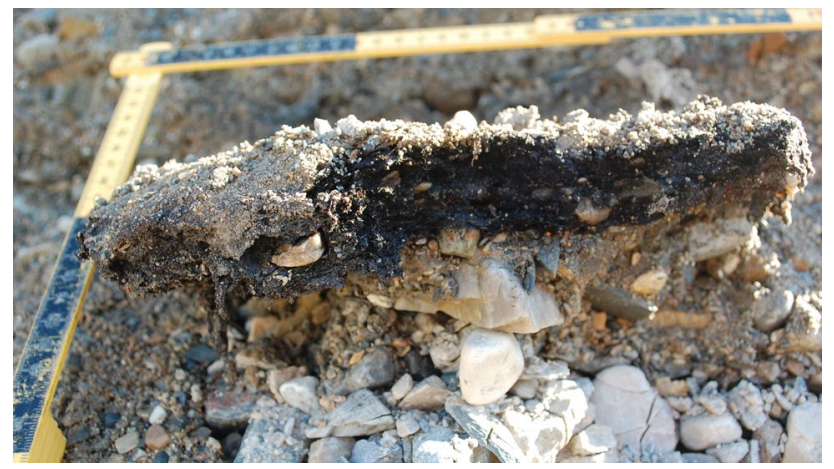

Fig. 11 Mat of sea weed extracted from the gravelly unit 6
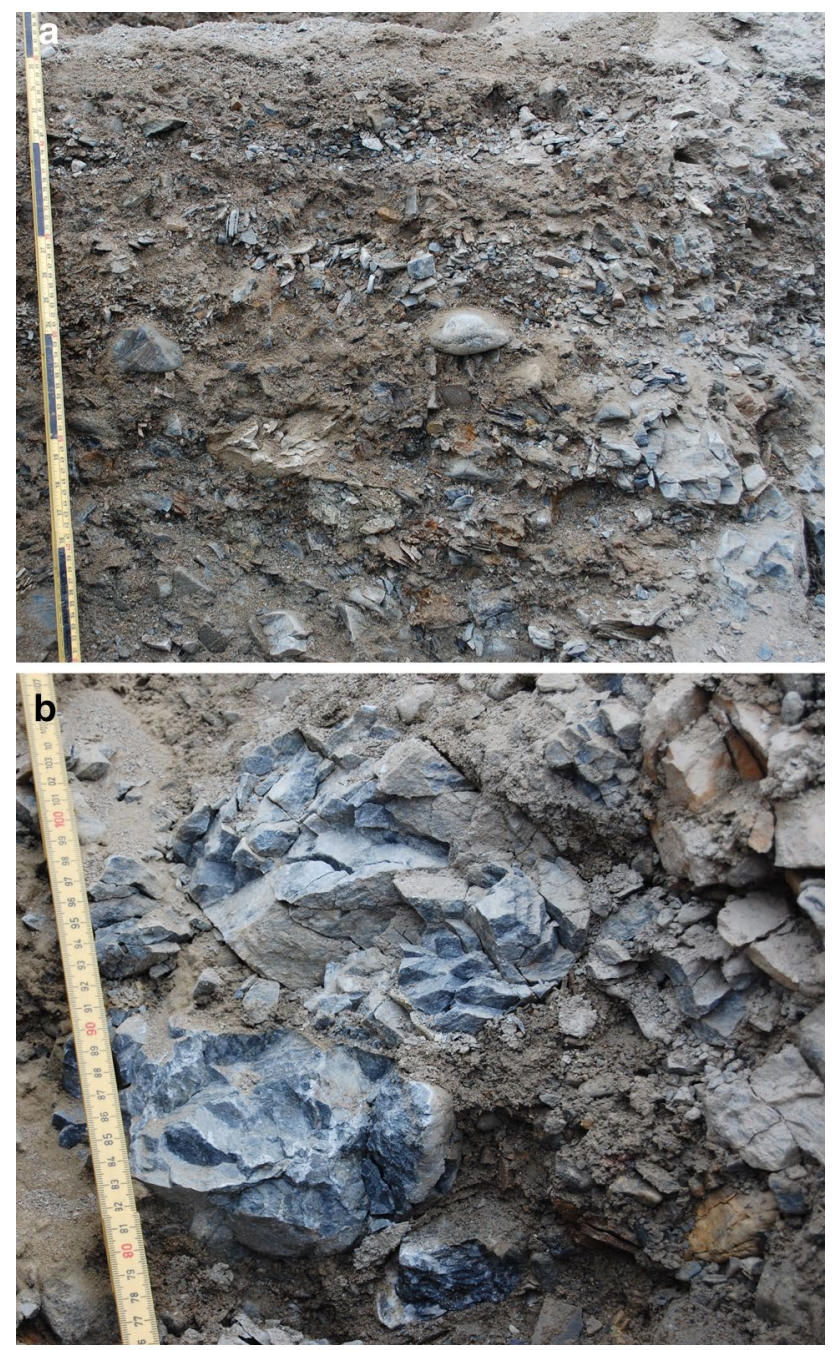

Fig. 12 Subunit 7a at site 103. a Overview. b Close-up of shattered marble clasts

part of unit 7 as we see it today (Fig. 4) could thus represent parts of a former, at least partly infilled, fluvial ravine. The material is similar to what is found in the present-day streams in the ravines along the coast, dominated by clasts of local bedrock, mixed with occasional erratic clasts. The littoral unit 6 at site 104 and the alluvial unit 7 at site 103, located at same altitude and being of similar age, suggest that the former stream was laterally replaced by littoral sediments (unit 6; Fig. 4) where it entered the sea, similar to the situation along the Kongsfjordhallet coast today.

A terrestrial origin of the unit as a whole is also supported by the in situ cracked clasts, mainly in subunit $7 \mathrm{a}$, and which are interpreted to be frost shattered [e.g. 60]. The undulating deformations are consistent with involutions caused by cryoturbation [e.g. 61, 62] and the diffuse sandy wedge (Fig. 13) may be an ice wedge or frost wedge cast. Combined with the presence of carbonate precipitates this suggests that the material in the upper part of unit 7 was exposed at, or close to, a ground surface for some time [cf. 59, 63].

\section{Unit 8: marine sands and silts}

Unit 8 is a $\sim 0.5$-m-thick unit that can be traced for $800 \mathrm{~m}$ (Fig. 4). It is a distinct marker bed with sharp lower boundary, and appears as a dark band a few metres below the top of the cliffs. However, it exhibits lateral and vertical variation in sedimentological characteristics, as well as in age (see below), and it has, therefore, been divided into two subunits, lower/older subunit $8 \mathrm{a}$ and the upper/younger subunit $8 \mathrm{~b}$.

Subunit $8 \mathrm{a}$ is found in the northwestern part of the sections (sites 101, 102). It consists mainly of decimetre-thick beds of massive gravelly sand or sandy gravel, commonly with some silt content (Fig. 14). Some of the silt beds are draped over underlying beds and current ripples are observed in a few sandy beds. Additionally, some layers are synsedimentary folded. The subunit contains more, and larger, cobbles and is thicker than subunit $8 \mathrm{~b}$. Clasts are generally subangular-subrounded (Fig. 14b), but some of the cobbles are fractured and exhibit carbonate precipitation. The precipitates occur on any side of the clast. Clast fabric shows a moderately preferred orientation SW-NE (Online Resource 3). Some boulder- or cobble-rich horizons occur, and some small $\mathrm{mm}$-sized shell fragments have also been found. The subunit is dated by OSL to $69-56 \mathrm{ka}$ (mean $60 \pm 4 \mathrm{ka} ; n=3$, Table 2).

Subunit $8 \mathrm{~b}$ is documented at sites 103 and 104 and wedges out to the southeast at site 104. It is generally sandy in its lower part and silty in the upper part; the boundary between the two parts is interfingering (Fig. 15a). The lower part consists of poorly sorted massive gravelly sand with scattered clasts, locally containing some silt; it is mainly matrix supported, but in places it can have higher cobble content and be clast supported. The upper part is better sorted and finer grained, consisting of massive or laminated, in places ripple laminated, sandy silt. Occasional larger clasts are observed in the silt, in places with bended laminae below (Fig. 15b). Clast fabric is variable, from girdle 

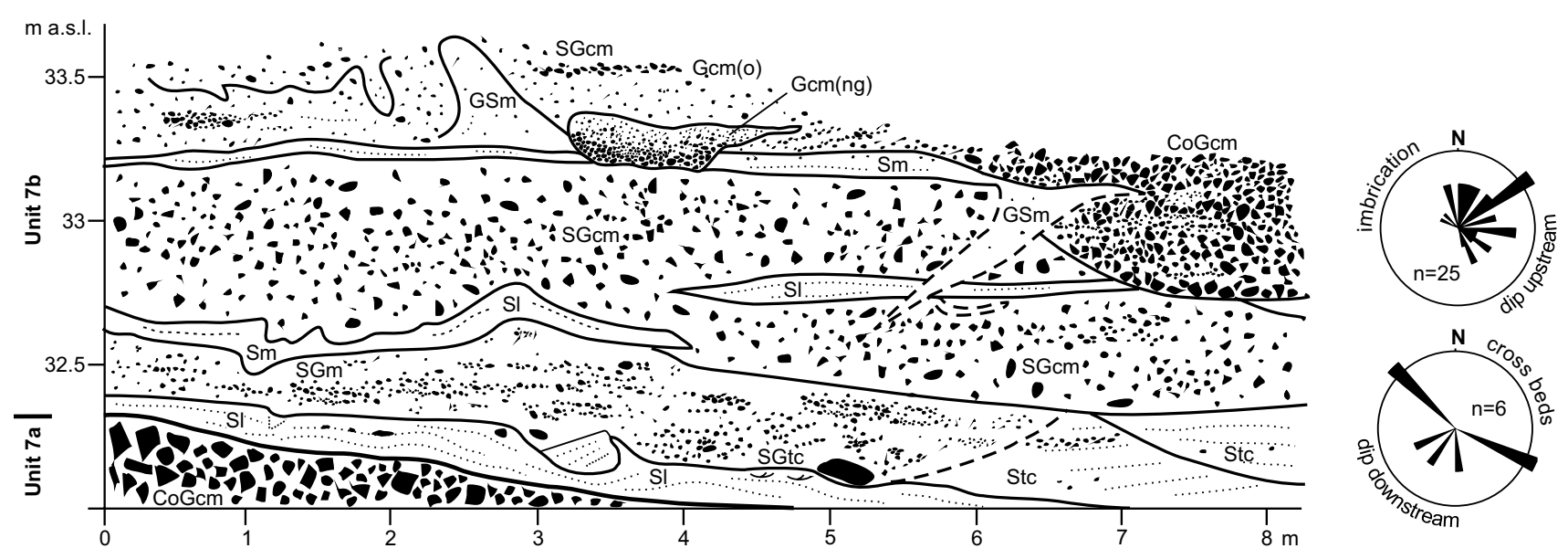

Fig. 13 Part of unit 7, mainly subunit 7b, with stream channel deposits at site 103. See Fig. 5 and Table 1 for legend

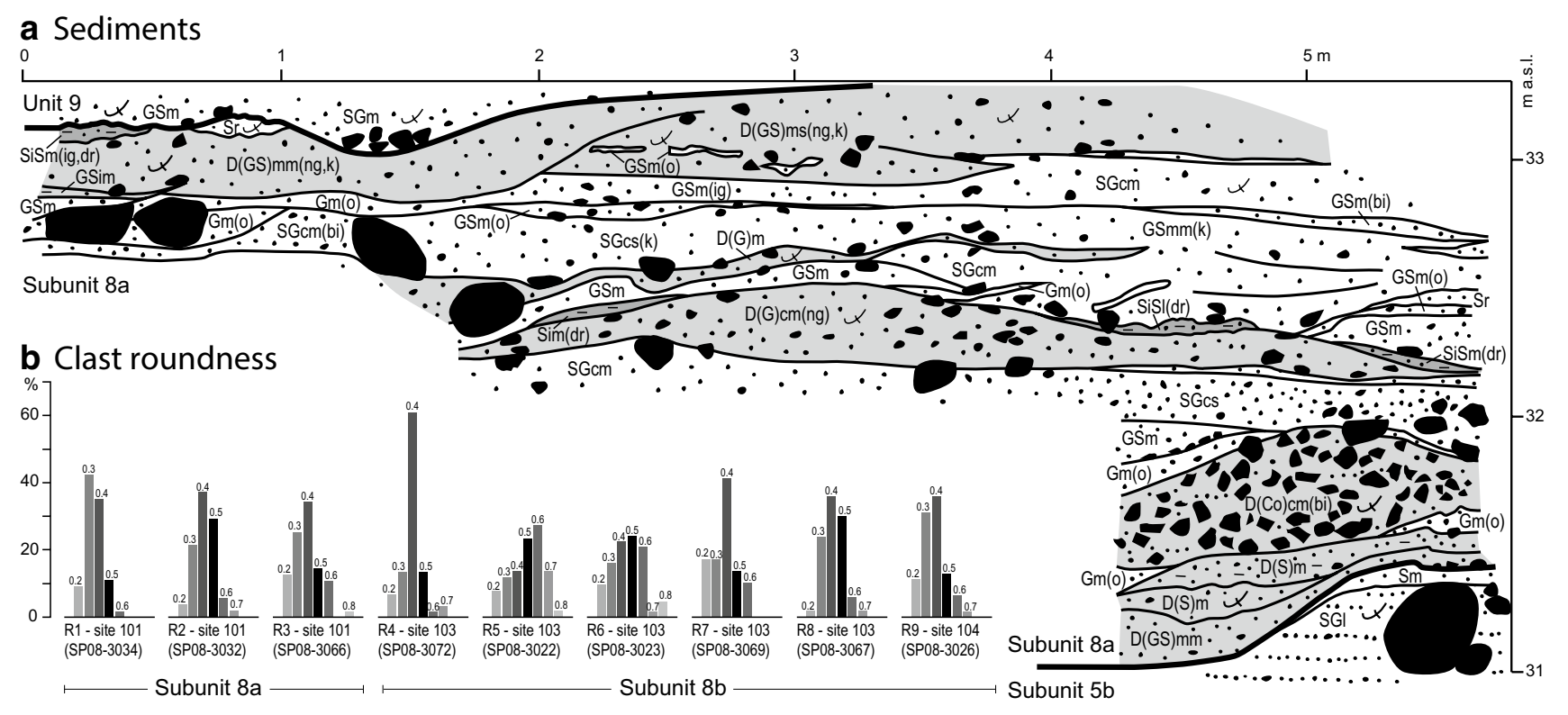

Fig. 14 a Subunit $8 \mathrm{a}$ at site 102 with lateral and vertical alternation between diamict and sorted sandy beds. The light grey shading highlights silty diamictic beds and the dark grey shading silty drapes, used

to cluster, preferred orientations (where found) is mostly NE-SW (Fig. 7, Online Resource 3). Shells, of which at least one was paired, have been found. Wedges or balls of the overlying sediments penetrate the upper part of the subunit in places. The subunit is OSL dated to 19-16 ka (mean $17 \pm 0.6 \mathrm{ka} ; n=3$, Table 2).

Subunit 8a contains few diagnostic features for a genetic interpretation. However, the frequent shell fragments as well as the sorted and alternating finer and coarser grained sediments, the draping silt and the ripples suggest a marine environment with some sorting by water and variable energy levels. The depositional processes may have been to infer a marine depositional environment. b Clast roundness data for both subunits, $8 \mathrm{a}$ and $8 \mathrm{~b}$. See Fig. 7 and Online Resource 3 for fabric data and Table 1 for legend

different types of sediment density flows [50], which could also explain the deformation structures. Transport direction probably was towards the present-day fjord. An alternative interpretation is that the sediments are alluvial in origin, with the cracked clasts and carbonate precipitation indicating a subaerial environment (cf. unit 7), but the unit would then not be expected to have such large lateral continuity.

Subunit $8 \mathrm{~b}$ is interpreted as marine mass-movement deposits, with debris flows dominating in the lower part and turbidity currents or concentrated density flows in the upper part [50], together with deposition from suspension. Dropstones [52] show that calving glaciers were present in 

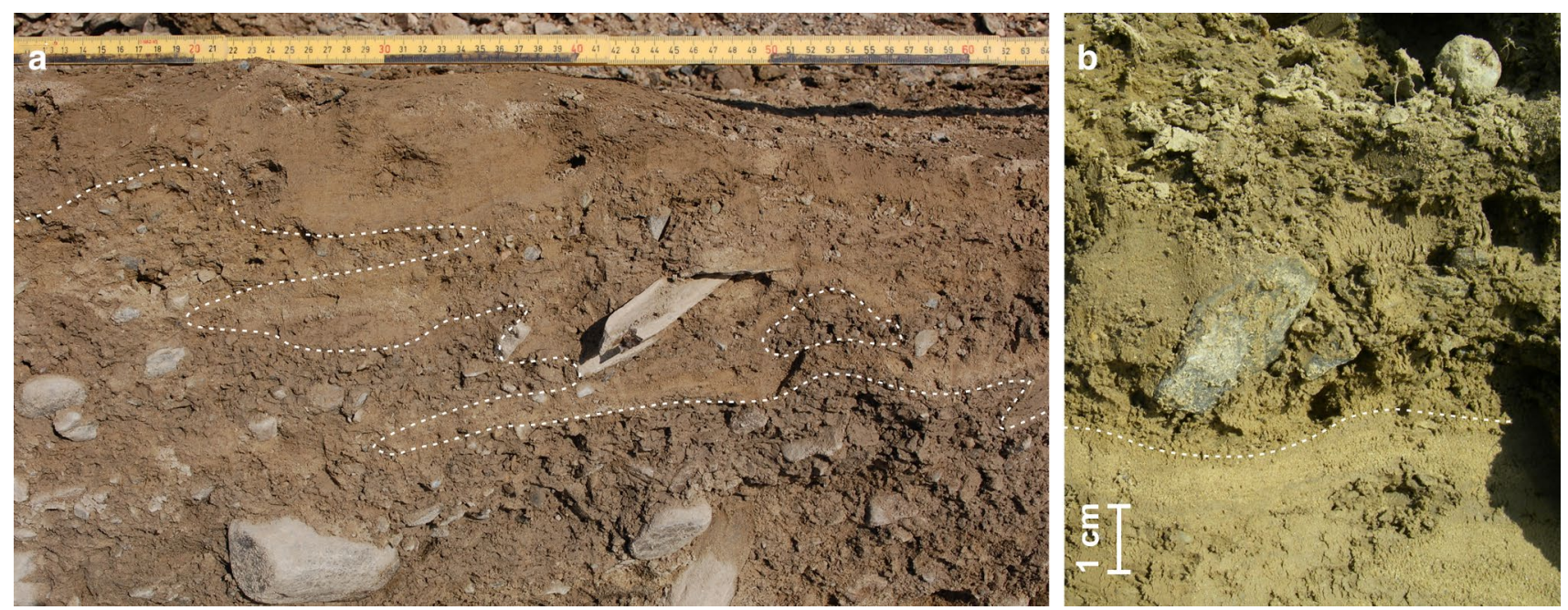

Fig. 15 Subunit $8 \mathrm{~b}$ at site 103. a The white, hatched line shows the interfingering contact between the lower massive, gravelly sandy beds and the upper, laminated sandy silty beds. b A small clast with bended lamina below

the fjord. The subunit was later, after deposition of unit 9 , exposed to cryoturbation, resulting in, e.g. ice-wedge casts (cf. "Unit 9: beach gravel with soil formation").

\section{Unit 9: beach gravel with soil formation}

Unit 9 consists of stratified gravelly sand and sandy gravel (Fig. 16). The coarser parts are clast-supported with either open framework, or a discontinuous matrix of silt with a vesicular structure. There is a predominance of horizontally oriented disc-shaped clasts. Many clasts have carbonate crusts on their undersides (up to stage IIa, Forman and Miller [59]). Some millimetre-sized shell fragments have been found. The unit is $1-2 \mathrm{~m}$ thick and can be mapped laterally for more than $800 \mathrm{~m}$ (Fig. 4). The lower contact to unit 8 is sharp and in places erosive (Fig. 16). The top of the unit forms the ground surface along most of the section, except where it is covered by modern solifluction (Unit 10). It can be traced ca $50 \mathrm{~m}$ inland by GPR where the surface is gently rising up to the marine limit marked by a break in the terrain (Fig. 3c). The surface in places displays patterned ground and is cut by ice-wedge polygons. The unit is dated by OSL to $16 \pm 0.8 \mathrm{ka}(n=1$, Table 2$)$ and by radiocarbon to $13.1-12.8$ cal. ka BP.

Unit 9 is interpreted as beach gravel, deposited at or above sea level in the beachface or berm zone [58,64]. This interpretation is based on the unit's stratification and the sediments' geomorphological expression, the shape of the clasts and the shell content. The cryoturbation, ice wedges and soil formation (pedogenic silt; Forman and Miller [59]) show that the sediments have been close to the ground surface for some time. The unit reaches an elevation (37-38 $\mathrm{m}$ a.s.l.; Fig. 3c) close to the marine limit of the last deglaciation

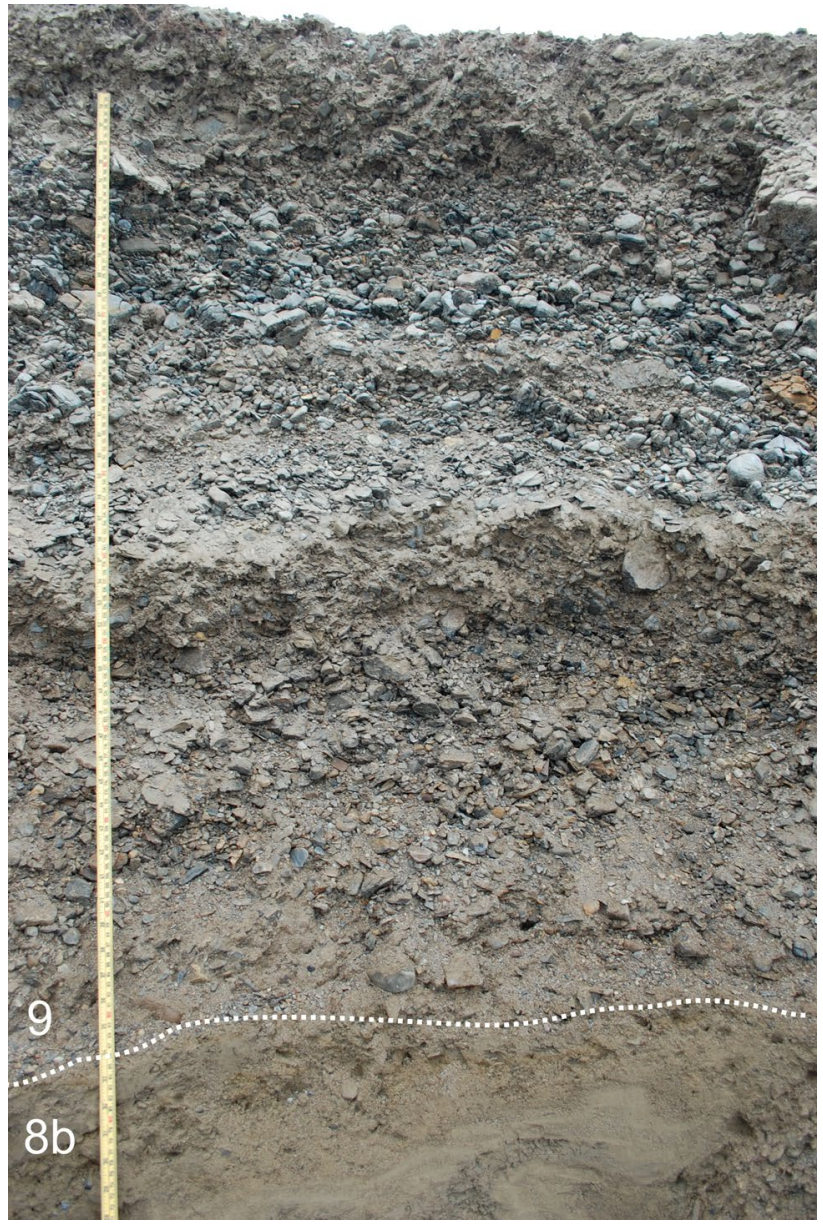

Fig. 16 The gravelly beach sediments of unit 9 overlying the siltysandy subunit $8 \mathrm{~b}$ at site 103 . Note horizons with pedogenic silt within the gravel. The top of unit 9 is the present-day ground surface 
(39 $\mathrm{m}$ a.s.1.; [20]) and the sediments are thus believed to have been laid down shortly after the ice retreated from the site.

\section{Unit 10: solifluction deposit}

Unit 10 is a $1-1.5-\mathrm{m}$-thick brownish, massive poorly sorted gravelly sand and sandy gravel. The lower contact to Unit 9 is sharp but not erosive. Some silt is present, more in the upper part than in the lower, and there are a few well-sorted silty sandy lenses. There is lateral variation from diffuse sub-horizontal sandy beds (1-3 dm thick) to deformed, gravel-dominated, largely clast-supported beds (Fig. 17a). Both sub-horizontal lenses of well-sorted sand and circular patches of clast-supported gravel occur. Clast roundness ranges from angular to subrounded and some clasts, particularly towards the top, are shattered. Carbonate precipitates are found at the undersides of many clasts [cf. 59]. Thin roots occur throughout the unit, and a few, very small shell fragments have been found. In the section, the unit is only exposed at site 104, where it has a lateral extent of $\sim 10 \mathrm{~m}$.
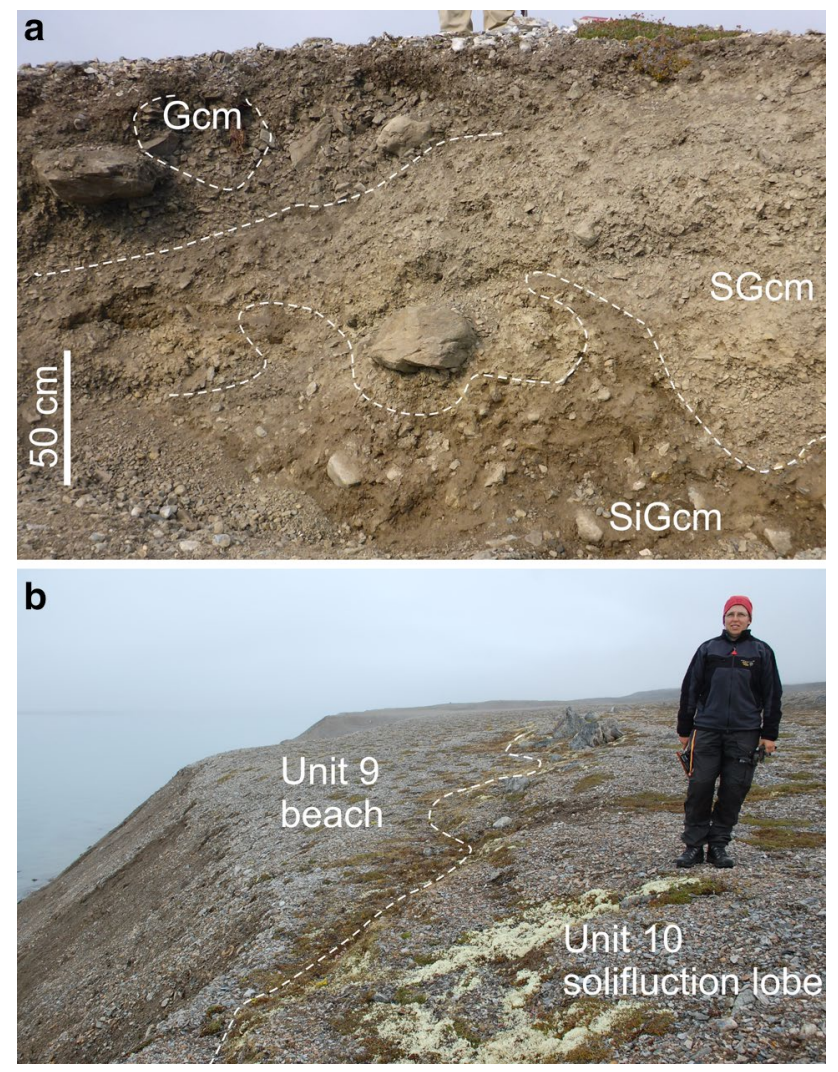

Fig. 17 Unit 10 at site 104. a Section through the deformed and gravelly part of the unit. The hatched lines show bed boundaries. b The unit's geomorphological expression as a solifluction lobe. The hatched line represents the front of the lobe, with its stone garland. Movement was from right to left in the photo and the most distal part of the lobe is currently being eroded at the coastal cliff
However, it is a part of an up to 0.4-m-high lobate feature that extends $\sim 65 \mathrm{~m}$ laterally and $15-30 \mathrm{~m}$ inland and which forms the ground surface. Small boulders mark the frontal limit of the lobe (Fig. 17b).

The unit is interpreted as a solifluction lobe; solifluction is used here in the sense of French [61] and include frost creep, gelifluction and/or plug-like flow. The interpretation is mainly based on the many soil indicators in the unit (frost-shattered clasts, carbonate precipitation, roots) and the unit's geomorphological expression. The lenses of sorted, clast-supported gravel likely represent former sorted strings, which are also present on the ground surface today. Buried sorted strings have similarly been described from the NyAllesund area across the fjord [65]. The source material for the lobe is likely the underlying and landward beach deposits, which have been subaerially exposed since shortly after deglaciation [66]. Assuming a conservative rate of movement of $1 \mathrm{~cm} /$ year $[67,68]$, a minimum age of the lobe is in the order of 1500-3000 years.

\section{Chronology}

The OSL ages range from 209 to $16 \mathrm{ka}$ and group within the stratigraphic units (Table 2; Figs. 4, 19). All OSL samples from Kongsfjordhallet showed some feldspar contamination, but are dominated by a fast signal component and fulfil standard quality criteria [dose recovery, recycling ratio, recuperation; cf. 10, 28]. The samples that contain aliquots close to saturation (R-081350/51, R-091303 and L-14036/37) may be considered minimum ages [42], but with two exceptions we treat these ages as true, see discussion below (4.2). The exceptions are samples R-081351 and R-091303, which are dominated by saturated aliquots $(>70 \%)$.

The ESR ages are within the range ca 80-40 ka (Table 3). The ages are all from units $2-4$, which were the only ones where shells suitable for ESR dating were found. The ages of the three different units overlap within the analytical error.

The radiocarbon age of a seal bone from unit 9 is $11,500 \pm 55{ }^{14} \mathrm{C}$ a BP $(13,120-12,765$ cal. a BP; sample no $\operatorname{LuS} 11,456)$.

\section{Discussion}

\section{Depositional environments}

\section{Subglacial: scarce direct traces of ice cover}

Although the Kongsfjordhallet sections have been repeatedly covered by glaciers and ice sheets during the last $200 \mathrm{ka}$ [6, 26], there is a conspicuous lack of tills in its stratigraphic record. Instead, most glaciations are only inferred from raised marine and littoral deposits (see "Marine and littoral: 
vital chronological keys and glacial indicators"). Only one unit (unit 3) is interpreted as a subglacial till, and it may represent a local flow style ("Event K-II (units 3-5, ca 130 ka)", cf. [2]) from an extended valley glacier, or possibly a tributary to a fjord glacier. This local ice-flow signature is similar to what has been noted for other sites on Svalbard, particularly on the west coast $[10,63,69-72]$ and has been assumed to reflect a predominantly low-activity, possibly even frozen-bed ice-sheet cover over these inter-fjord areas [2].

At Kongsfjordhallet, however, we are in a fjord area, and we know that ice streams were active in Kongsfjorden at least during the Late Weichselian [19, 27], and presumably also during earlier glaciations. The overall lack of subglacial deposits may be a result of either non-deposition or erosion. Non-deposition could be due to ice-stream confinement to the central part of the fjord, or perhaps partly due to the upstream Blomstrandhalvøya (Fig. 1b) 'protecting' Kongsfjordhallet from the most active ice. Erosion by later glacial or non-glacial processes could also have removed any glacial deposits, but must then have occurred late during each glacial event, before the marine sediments were deposited.

\section{Marine and littoral: vital chronological keys and glacial indicators}

Seven out of the ten units at Kongsfjordhallet have been deposited in a marine or littoral environment (units 1, 2, $4,5,6,8,9)$. They are also the volumetrically dominating sediments (Figs. 4, 19), similar to many other coastal stratigraphic sites in the Arctic [e.g. 6, 73]. The depositional processes at Kongsfjordhallet range from suspension settling and mass movements in lower energy (deeper) settings, to wave reworking in higher energy (shallower) environments. Although some successive units show a shallowing-upward trend, no complete sequence of shallowing-upward due to isostatic rebound [8-10] has been observed. Nevertheless, all units are found above the present sea level. They are thus evidence of former high relative sea levels in the area, suggesting preceding large-scale glaciations ('glacio-isostatic event stratigraphy', cf. Alexanderson et al. [13]). When direct evidence of glaciation, such as tills, is missing, the raised marine sediments are thus key evidence for the reconstructions of the glaciation history.

Due to their sediment properties and fossil content, these deposits are also vital for establishing a chronology for the glacial events. Although they only provide maximum or minimum ages of glaciations, they are commonly the only datable units in stratigraphic sections. Their fossil content and the sand's exposure to sunlight during deposition make them suitable for absolute dating techniques such as radiocarbon luminescence dating, as well as for relative dating and palaeoceanographic reconstructions through proxies such as molluscan and foraminiferal faunas, as well as amino acid chronology [e.g. 11, 28, 74].

The marine and littoral units are usually fairly sedimentologically homogeneous (e.g. massive or stratified sand or gravel), and in the case of gravelly units practically difficult to excavate in good exposures. This makes it hard to identify any hiatus(es) within these sediments and thus to recognise if they represent more than one postglacial event. Geochronology is then a crucial tool. For example, it is only through absolute dating that we were able to separate unit 5 from unit 6 , and subunit 8 a from 8 b. Similar observations have been made in marine or littoral units at, e.g. Leinstranda [10] and Poolepynten [14, 69] and a fairly extensive dating program with laterally and vertically distributed samples must be recommended when working with this type of sediments and questions.

\section{Alluvial: a rare treat}

Although alluvial and fluvial deposits and associated landforms are relatively common on Svalbard today, e.g. as alluvial fans and glacifluvial valley fills and sandar [56], such sediments are rarely described from the coastal stratigraphic records (but see, e.g. Lønne and Nemec [75]) though they are found at some inland sites [e.g. 76]. The coastal sections are, not surprisingly, instead dominated by (glaci)marine and littoral deposits (cf. "Marine and littoral: vital chronological keys and glacial indicators"). This makes unit 7 at Kongsfjordhallet an interesting rarity.

The alluvial sediments are evidence of subaerial deposition, and like the periglacial features ("Periglacial: evidence of ice-free conditions") they indicate ice-free conditions at the site. However, alluvial sediment could be seen as an indicator of local glaciation nearby as the (large) amount of water and sediment must have a source. In an otherwise fairly dry area as Svalbard such a source is likely to be a glacier. The alluvial deposits could thus represent a local glaciation style [2], with valley glaciers advancing during a late phase of regional glaciation or rather an early deglaciation stage when relative sea level was still high. The environment may have been similar to the last deglaciation, when local glaciers advanced at Kongsfjordhallet after the retreat of the main ice sheet [19]. Although the meltwater then seems dominantly to have caused erosion (channel formation) rather than deposition, and the erosion appears to have stopped close to the marine limit [18].

Even if (fossil) meltwater channels occur across the Kongsfjordhallet plain, today the main drainages are focussed into two ravines and one canyon, partly controlled by bedrock structures $[18,19]$. Thus, the location of the drainages were probably similar during several events, which would explain the location of unit 7 close to the present-day ravine just SE of site 103 (Fig. 4). 


\section{Periglacial: evidence of ice-free conditions}

At Kongsfjordhallet, the results of different periglacial surface processes have been identified in the stratigraphic record: solifluction (unit 10), cryoturbation and patterned ground formation (units $7,8,10$ ), ice-wedge formation (units 7,9 ), frost shattering (unit 7) and soil formation with carbonate precipitation and silt infiltration (units 9, 10). Features that result from these processes are positive evidence of ice-free conditions [cf. 26, 77]. However, although the processes are common in the arctic environment today, their signatures are rarely reported from the Quaternary stratigraphic record, with the exception of ice-wedge casts and palaeosols. This may be due partly to poor preservation potential of terrestrial sediments, and partly attributed to the difficulty of correctly identifying some of these features in the stratigraphy [e.g. 61].

Solifluction may, for example, give rise to diamictons that can be hard to differentiate from tills, especially if the diamicton is reworked from glacial deposits and, e.g. contains striated clasts of different lithologies. In the case of unit 10 , our interpretation was aided by the geomorphological expression of the unit on the surface (Fig. 17b) but macroscopic, sedimentological features such as low compactness, limited lateral extent and evidence of soil (e.g. organic material such as roots) were also key to identifying the unit as a solifluction deposit. Although solifluction commonly results in a massive, matrix-supported diamicton [61], lenses of sorted and/or clast-supported material may occur as a result of input from other slope processes (e.g. rockfall, slopewash) or due to frost-related sorting [78]. In this case, we hypothesise that the lenses may be buried sorted stripes. A strong fabric parallel to the slope has also been advocated as a diagnostic criteria for solifluction deposits [79], but may not help in distinguishing it from a subglacial till, unless the ice-movement direction is known to be different from the direction of slope.

Of the features seen at Kongsfjordhallet, palaeosols are the ones that most commonly have been described from other pre-Late Weichselian stratigraphic sites in the area, such as Brøggerhalvøya [9, 10, 59], northern Prins Karls Forland [70] and Bellsund in SW Spitsbergen [63]. The soils are generally formed in beach deposits, or other coarsegrained sediments, and are represented by horizons with pedogenic silt and carbonate precipitation, typically combined with weathered, frost-shattered clasts [e.g. 80]. The amount of weathering products (e.g. depth and magnitude of silt infiltration) has been used for a relative estimate of duration of surface exposure $[59,81]$ in some Arctic areas. However, other studies have shown significant spatial variation due to local factors and a less clear relationship between duration of exposure and the formation of pedogenic horizons $[80,82]$.

\section{Facies model}

The succession of depositional environments, represented by the different sediment units described above, is largely controlled by relative sea level. Global sea level has been relatively low during the last $200 \mathrm{ka}$, with the exception of the last interglacial [12], and there is no evidence of significant tectonic activity in the Kongsfjorden area. Consequently, over time, the high relative sea-level events have mainly been controlled by glacial isostasy. As mentioned in "Introduction", this glacioisostatic signal-called emergence cycles [9] -have for a long time been used as means of identifying and separating glacial events. A facies model for such an emergence or rebound cycle was also suggested by Alexanderson et al. [10], and here we add to that model by also including terrestrial deposits (Fig. 18).

Our facies model is based on the sediments and stratigraphies at Leinstranda [10] and at Kongsfjordhallet (this study). The sedimentary record shown in Fig. 18c is an idealised record, representing glacial advance and overriding (facies A), deglaciation with isostatic rebound and successively shallower water (facies B-E) and eventually fluvial and periglacial processes (facies F) on ice-free land. In most cases, only few of the facies are actually found per sequence. However, it is important to recognise that even if the record is incomplete, e.g. lacking the subglacial till, it still implies a regional glaciation and subsequent deglaciation.

The time represented by the sedimentary record is difficult to estimate. Most time is likely recorded in the subglacial facies (A; Fig. 18c), whereas the shallowing-upward sequence (B-E) may represent a few thousand years. This is based on sea-level change during the last deglaciation as recorded by shore-line displacement. The postglacial sealevel lowering was initially slow in western Svalbard, but after ca 3000 years it dropped rapidly to reach present-day sea level [66]. If the alluvial deposits (F) can also be connected to a high relative sea level, e.g. by interfingering with beach deposits, they formed within this time period of high relative sea level too, while the periglacial processes, resulting in, e.g. solifluction deposits (F), could have occurred at any time subsequent to land exposure.

\section{Chronological challenges}

The results are not entirely consistent between the three different numerical dating methods we have used. The largest difference is between OSL and ESR: the ESR ages are significantly younger than the OSL ages for unit 2 (79-41 ka vs $172 \pm 13 \mathrm{ka})$ and units 4-5 (66-45 ka vs $139 \pm 7 \mathrm{ka})$. Here, we prefer the OSL chronology because the OSL ages change in stratigraphic order and independent data (see "Event K-II (units 3-5, ca $130 \mathrm{ka}$ )", "Event K-V (units 8b-10, since ca $17 \mathrm{ka}$ )") suggest that the last interglacial and the 


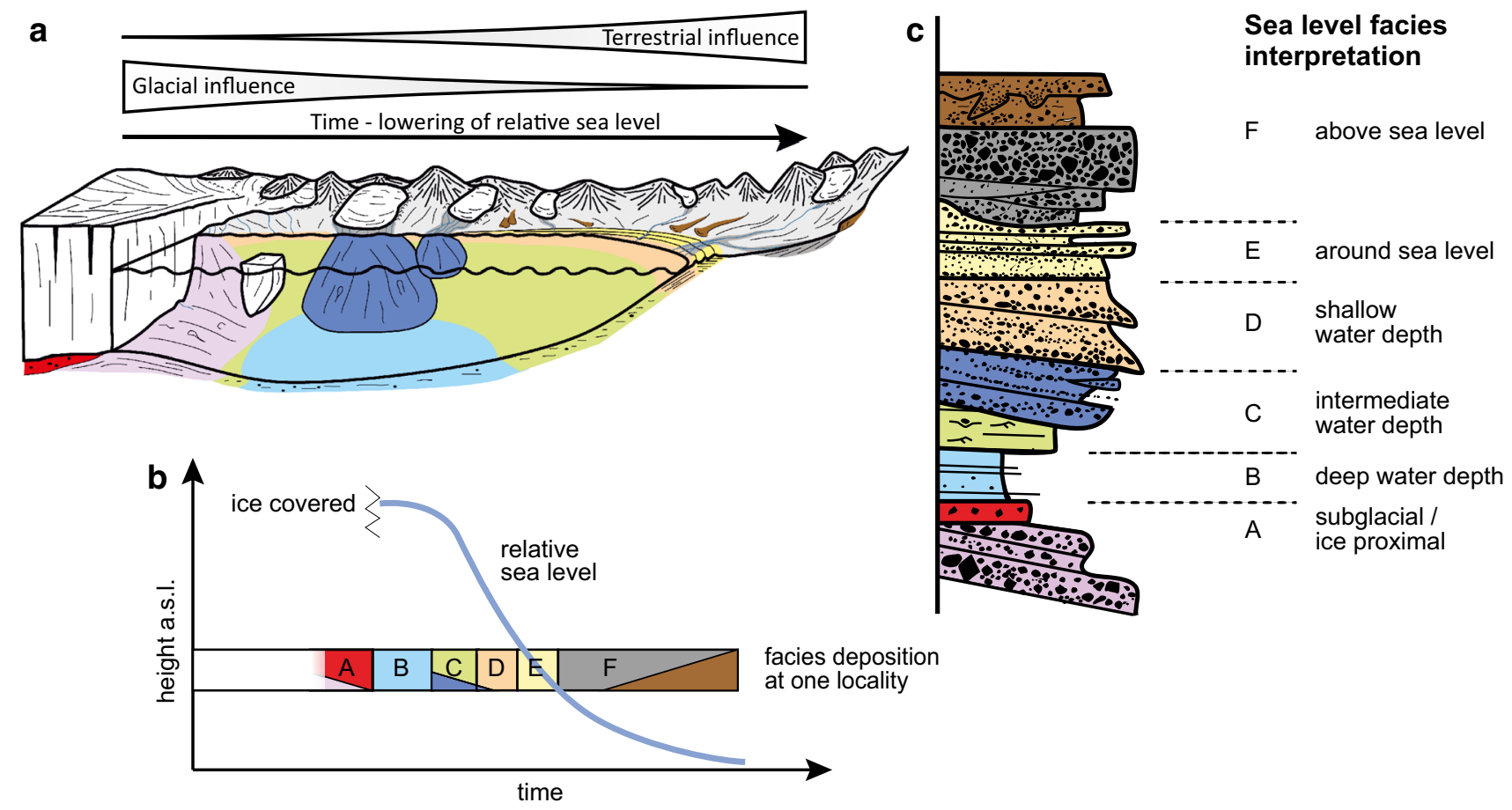

Fig. 18 Facies model for an emergence cycle based on the sediments found in the Kongsfjorden area. Modified and expanded from Alexanderson et al. [10]. For colour legend, see Fig. 19. a A schematic model of depositional environments found in the Kongsfjorden area [modified from 10]. b The relationship of the different facies to local sea level. c Idealised stratigraphic record of a complete emergence cycle with focus on relative sea-level change [modified from 10]

marine and littoral deposits that form coarsening-upward (regressional) sequences or emergence cycles. Based only on lithostratigraphy we can identify three such sequences, each starting at one of the marker beds (units 1,3/4 and 8); this is the minimum version shown in Fig. 19. However, if we also include the chronological information, mainly the OSL ages and their spatial distribution, we are able to identify five emergence cycles (maximum version in Fig. 19). This is because we divide the sandy-gravelly sediments above unit 4 into two sets that are laterally separated: an older set (unit 5) at sites 101-103 and a younger set (unit 6) at site 104. The same situation is true for unit 8 , which is split into subunits 8a and 8b (Fig. 4, cf. "Unit 8: marine sands and silts").

Below, the events will be summarised (for details on depositional environments, see "Sediment units") and put into a regional context by correlating to other stratigraphic sites on Svalbard, mainly Leinstranda on the Brøggerhalvøya peninsula across the fjord [10, 28] and Kapp Ekholm on central Spitsbergen $[8,15]$ as well as to other records from Svalbard and in the Barents Sea region [e.g. 6, 84]. The different studies span almost 40 years, and several sites have not been reinvestigated with modern dating methods. However, we regard these correlations (Fig. 20) as the best approximation from the available data.

The event stratigraphy (Figs. 19, 20) is based on the high relative sea-level events as interpreted from the glaciomarine, 


\section{Kongsfjordhallet}

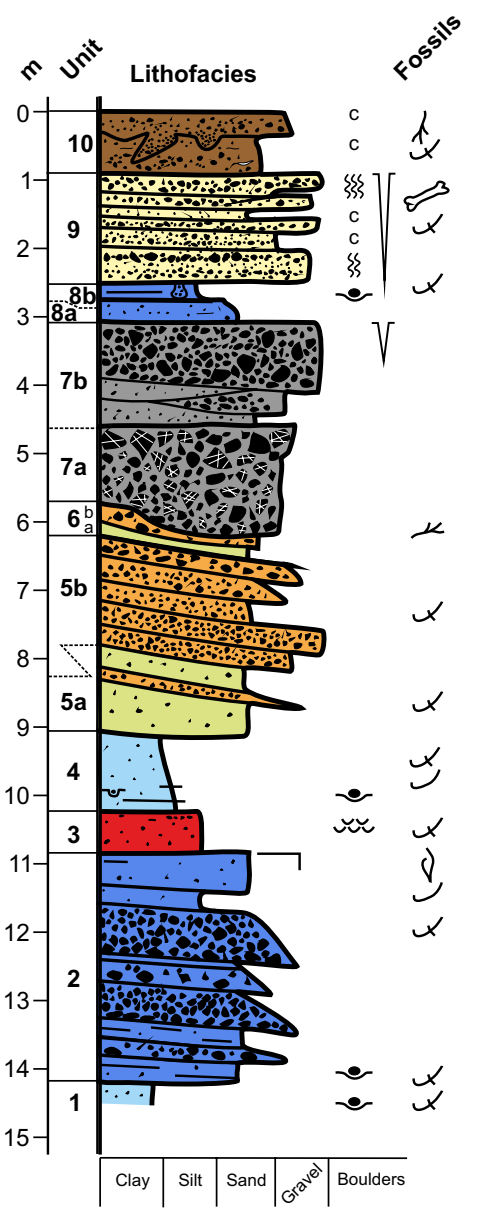

solifluction deposit alluvial sand and gravel beach gravel
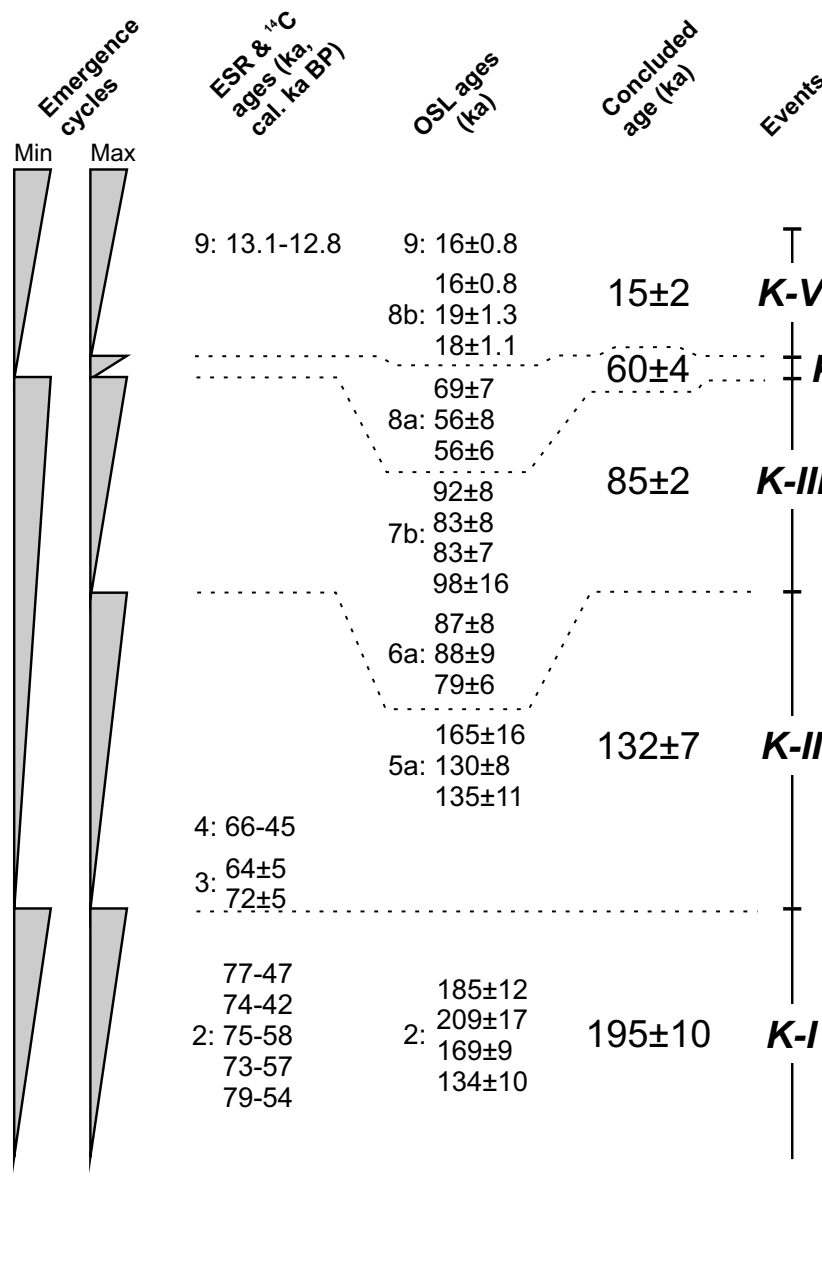

Facies successions

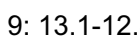

9: $16 \pm 0.8$

$16 \pm 0.8$

8b: $19 \pm 1.3$

$18 \pm 1.1$

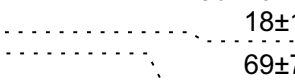

$69 \pm 7$

8a: $56 \pm 8$

$56 \pm 6$

$92 \pm 8$

7b: $83 \pm 8$

$83 \pm 7$

$98 \pm 16$

$87 \pm 8$

6a: $88 \pm 9$

$\because 79 \pm 6$.

$165 \pm 16$

5a: $130 \pm 8$

4: $66-45$

$135 \pm 11$

3: $\begin{aligned} & 64 \pm 5 \\ & 72 \pm 5 \\ & .\end{aligned}$

2: $\begin{aligned} & 185 \pm 12 \\ & 209 \pm 17 \\ & 169 \pm 9 \\ & 134 \pm 10\end{aligned}$

$132 \pm 7$

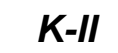

K-II

\begin{tabular}{|l|l|l|}
\hline B & C & D \\
\hline
\end{tabular}

$77-47$
$74-42$

2: $75-58$

73-57

79-54

$15 \pm 2 \quad$ K-V

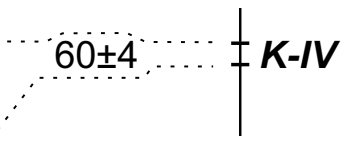

$85 \pm 2 \quad K-I I I$

C D

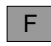

\section{Facies interpretation}

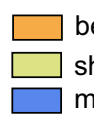

beachface gravel

shoreface sand

marine density flow deposits glaciomarine mud or diamicton subglacial till

ice-proximal glaciomarine diamicton
Fig. 19 Composite log of Kongsfjordhallet (sites 101-104) with sediment ages, event stratigraphy, facies interpretation and facies succession within each unit (Fig. 18). Two versions of the number of emergence cycles is shown, a minimum version based only on lithostratigraphy and a maximum version based on both litho-

Event K-I (units 1-2, ca 195 ka) Event K-I started with relatively deep glacimarine conditions (unit 1 ; facies B in our model; Fig. 18) that became shallower and less glacially influenced, but received large sediment input from a nearby source on land (unit 2, facies C) (Fig. 19). The relative sea level during the event was at least $25 \mathrm{~m}$ a.s.l. Such a high relative sea level implies a preceding regional glaciation, and the large sediment input shows that local glaciers existed in the mountains inland of Kongsfjordhallet while sea level was still high. and chronostratigraphy, see further discussion in text. Note that the ages for events K-III and K-V are the weighted means of the ages from subunits $6 \mathrm{a}$ and $7 \mathrm{~b}$ (OSL), and subunit $8 \mathrm{~b}$ and unit $98 \mathrm{~b}$ (OSL and $\left.{ }^{14} \mathrm{C}\right)$, respectively. For events K-I and K-II the weighted ages are excluding unreliable samples, cf. Table 2. See Fig. 5 for legend

We tentatively correlate Event K-I, which has been OSLdated to $195 \pm 10 \mathrm{ka}(172 \pm 13 \mathrm{ka}$ when not excluding an unreliable age; Table 2), with event I (units 1-4; $185 \pm 8 \mathrm{ka}$ ) at Leinstranda [10, 28], possibly also episode D at NW Brøggerhalvøya (489-178 ka; Miller [9]) (Fig. 20). These units represent similar depositional environments, including the large input of sediment from land, and both occur below a unit interpreted to be of last interglacial age. The event is thus likely placed in marine isotope stage (MIS) 6 or late MIS7. Deposits on Kongsøya (unit B; Ingólfsson et al. [7]) and at Kapp Ekholm (Formation B; Forman [85]) have been 


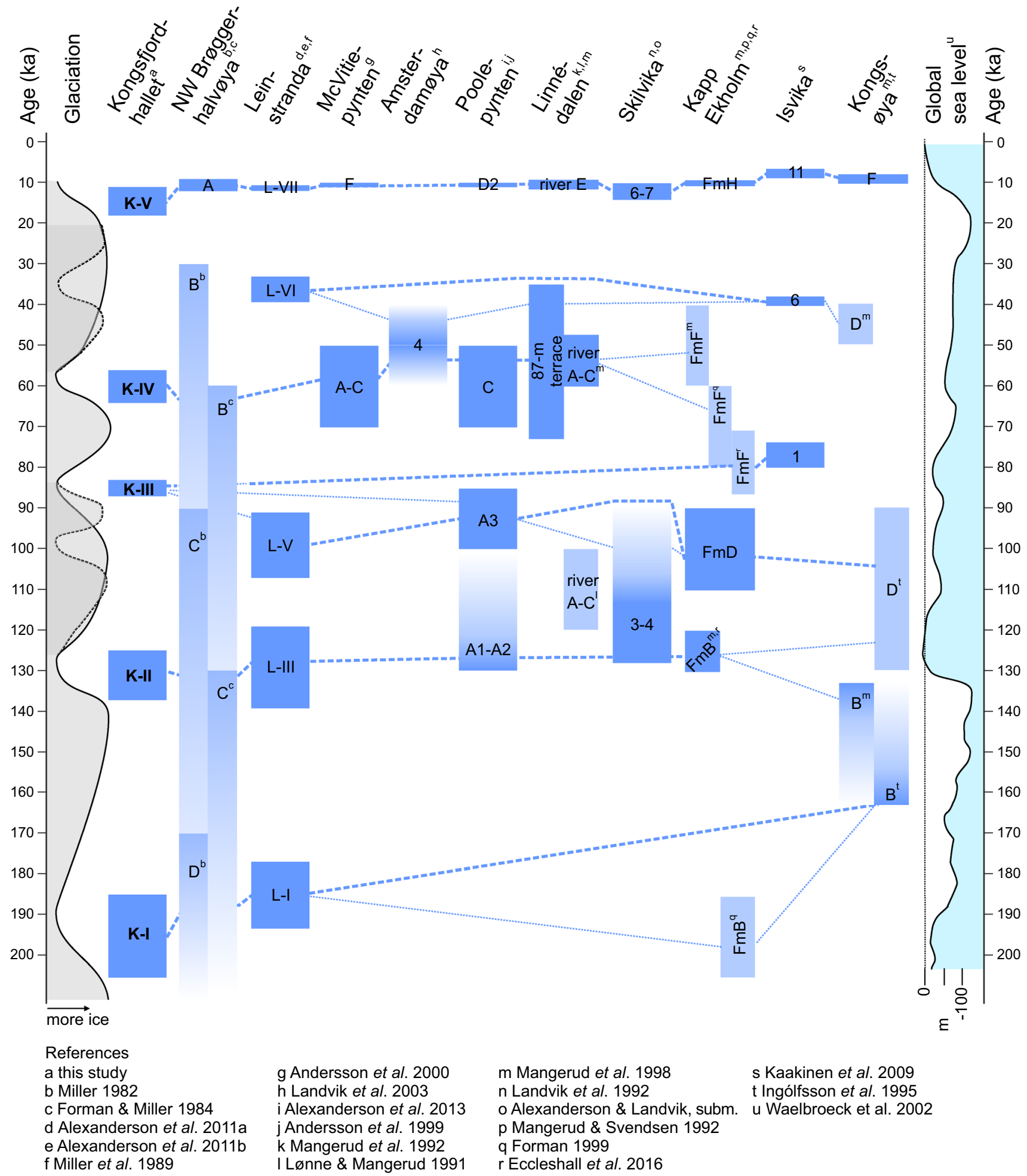

Fig. 20 Correlation of high relative sea-level events in the SvalbardNW Barents sea region, including a schematic glaciation curve (left) showing the intervening regional glaciations and a global sea-level curve [12] (right) for comparison. The numbers or letters in the blue squares denote events or units as reported in the original publications.
Light blue colour represents uncertain or debated age of the event/ unit. Thicker, hatched lines show our preferred correlations, whereas thinner, dotted lines show alternative correlations discussed in the text 
suggested to be of this age, but have by other authors been placed in younger episodes $[6,15]$.

Event K-II (units 3-5, ca 130 ka) Starting with a glaciation (unit 3), Event K-II is characterised by a shallowing-upward sequence from glaciomarine (unit 4) over shoreface (subunit 5a) to beachface (subunit 5b) settings, i.e. encompassing facies A-D (Figs. 18, 19). The glacier that deposited the unit 3 till must have been warm based, but directional evidence is conflicting (see "Unit 3: glacial diamicton"). It is possibly the result of local glaciers from the Kongsfjordhallet hinterland (in the north), which were reworking material previously deposited by glaciers moving from the inner fjord area (east). That may suggest till deposition during a late, local phase of glaciation (local flow style; Landvik et al. [2]). The relative sea level at deglaciation was probably at least $\sim 50 \mathrm{~m}$ a.s.l., as shown from the inland extent of the units in the GPR profiles (e.g. Fig. 3). Perhaps the unit may even be correlated with beach sediments reported at up to $80 \mathrm{~m}$ a.s.l. by Lehman and Forman [20] and Houmark-Nielsen and Funder [22], but this has not been confirmed with absolute ages.

The event has been dated to $132 \pm 7 \mathrm{ka}(139 \pm 7 \mathrm{ka}$ when not excluding an unreliable age; Table 2), i.e. the transition to the last interglacial (MIS 5e), and interglacial conditions are also supported by a diverse foraminiferal fauna [86, 87]. We thus correlate the event with event III (units 8-11) at Leinstranda [129 $\pm 10 \mathrm{ka}$; Alexanderson et al. 10, 28], and further with the events represented by units A1-A2 at Poolepynten (130-100 ka; Alexanderson et al. [14]), by Formation B at Kapp Ekholm (130-120 ka; [6, 8, 15]) and by units 3-4 at Skilvika [63, 88] (Fig. 20). It may also correlate with event $\mathrm{C}$ on NW Brøggerhalvøya, although that event is poorly constrained in age: 290-130 ka (beach ridges; [59]) or 260-90 ka (stratigraphy; [9]).

Event K-III (units 6-7, ca 85 ka) During Event K-III there is a transition from shoreface (subunit 6a) to beachface (subunit $6 \mathrm{~b}$ ) to alluvial and periglacial (unit 7) conditions, thus from a marine into a terrestrial environment (facies $\mathrm{C}-\mathrm{F}$; Figs. 18, 19). The deposition in these two settings was partly contemporaneous, with the littoral and alluvial environments replacing each other laterally, but the alluvial sediments (unit 7) are stratigraphically above the littoral ones (unit 6). During deposition of unit 6 the relative sea level was at least $30 \mathrm{~m}$ a.s.l., during deposition and subsequent weathering of unit 7 at most $31 \mathrm{~m}$ a.s.l.

The OSL ages for the littoral and the alluvial deposition overlap ( $84 \pm 4$ and $87 \pm 4$ ka, respectively) and the units are also considered to be contemporaneous within the resolution of the dating method, and the weighted mean for the combined unit 6/7 is $85 \pm 2 \mathrm{ka}$. This age matches well with the early part of the Kapp Ekholm interstadial (Formation F at Kapp Ekholm; Mangerud and Svendsen [8]) as dated by Eccleshall et al. ([15]; ca $80 \mathrm{ka}$ ), as well as with the Early Weichselian interstadial recognised in Nordaustlandet (80-76 ka, unit 1 at Isvika; Kaakinen et al. [16]) (Fig. 20). The event may be also be correlated with the slightly older event V (units 15-17) at Leinstranda [99 $\pm 8 \mathrm{ka} ; 10,28]$ and with the event represented by unit $\mathrm{A} 3$ at Poolepynten (100-85 ka; Alexanderson et al. [14]). However, it is possible that these two events - at least the one at Leinstrandarepresent an earlier Early Weichselian interstadial (MIS 5c) than event K-III at Kongsfjordhallet, which falls into MIS 5a. This would support the notion that there were two major Early Weichselian glaciations as suggested in the revised glaciation curve of Eccleshall et al. [15].

Event K-IV (subunit 8a, ca $60 \mathrm{ka}$ ) Event K-IV is represented by one unit only (subunit $8 \mathrm{a}$ ). The relative sea level was at least $36 \mathrm{~m}$ a.s.l. and subunit $8 \mathrm{a}$ was deposited by sediment density flows into a marine environment. No regressional trend is recorded in the sediments (facies C; Figs. 18, 19).

This high relative sea-level event is dated to $60 \pm 4 \mathrm{ka}$, which places it at the transition between MIS4 and MIS3. No event of this age has been documented at Leinstranda, but event K-IV can be correlated to events represented by units A-C (or only unit C) at McVitiepynten $(70 \pm 10 \mathrm{ka}$; Andersson et al. [70]), unit $\mathrm{C}$ at Poolepynten (70-50 ka; Alexanderson et al. [14]) and to deposits in the Linnédalen, both the 87-m terrace $(54 \pm 19 \mathrm{ka}$; Mangerud et al. [6, 89]) and units A-C (57 $\pm 8 \mathrm{ka}$; Lønne and Mangerud [90]; Mangerud et al. [6]) (Fig. 20). The event may possibly correlate to Formation $\mathrm{F}$ at Kapp Ekholm if the ages according to Mangerud et al. [6; 60-40 ka] and Forman [85; 70 $\pm 10 \mathrm{ka}]$ are used instead of those from Eccleshall et al. [15], cf. "Event K-III (units $6-7$, ca $85 \mathrm{ka}$ )" above. The slightly younger sediments at Amsterdamøya (59-40 ka; Landvik et al. [91]) may also belong to the same event. A deglaciation of a regional ice sheet at this time is supported by IRD and $\delta^{18} \mathrm{O}$ records together with foraminiferal faunas from core HH11-09GC north of Svalbard, which suggests ice-sheet disintegration and retreat in early MIS3 [84].

Event K-V (units $\mathbf{8 b}-\mathbf{1 0}$, since ca $\mathbf{1 7} \mathrm{ka}$ ) The regressional sequence of Event $\mathrm{K}-\mathrm{V}$ is represented by debris flows and turbidity currents in marine conditions (subunit $8 b$ ) succeeded by beach gravel (unit 9) deposited at or just above sea level (facies C, E-F; Figs. 18, 19). The beach gravel was then subjected to periglacial conditions for some time and locally covered by solifluction lobes (unit 10). The sea level was around $35 \mathrm{~m}$ a.s.l. during deposition of unit 9 , and subsequently lower.

Subunit $8 \mathrm{~b}$ is OSL dated to $17 \pm 0.6 \mathrm{ka}$ and unit 9 to $16 \pm 0.8 \mathrm{ka}$ by OSL and 13.1-12.8 cal. ka BP by radiocarbon (Table 2). Morphologically, the surface of the beach sediments can be mapped to the marine limit nearby (39 $\mathrm{m}$ a.s.l.; 
[20]) and units $8 \mathrm{~b}$ and 9 should thus have been deposited shortly after deglaciation. The deglaciation of the central part of Kongsfjordhallet took place before $14.4 \pm 0.3$ cal. ka $[19,20]$. Compared to this deglaciation age and the radiocarbon age of unit 9, the OSL ages thus seem to overestimate the true age by $2-4 \mathrm{ka}$, probably due to incomplete bleaching (see "Chronological challenges"). The true age of these deposits is, therefore, most likely 15-13 ka. Raised marine sediments from the same event, the last deglaciation, have been found at most stratigraphic sites on Svalbard (Fig. 20).

The soil formation in unit 9 has taken place since the unit was raised above sea level. There is likely a hiatus between the deposition of unit 9 and the overlying solifluction (unit $10)$.

Events L-V and L-VI (ca 100 and $35 \mathrm{ka}$ ) We have also included events L-V and L-VI described from the nearby Leinstranda [10, 28], only $18 \mathrm{~km}$ away (Fig. 1b). Event L-V is characterised by a relatively thick regressional sequence from glacimarine to shoreface to beachface sediments (units 15-17; facies $\mathrm{A}-\mathrm{D})$ that is dated to $99 \pm 8 \mathrm{ka}[10,28]$. We correlate this event to the event represented by unit A3 at Poolepynten (100-85 ka; Alexanderson et al. [14]) and Formation D at Kapp Ekholm (ca 100 ka; Mangerud et al. [6]). It may also be correlated to units 3-4 at Skilvika if the younger, alternative age of those deposits is preferred [63, 88, cf. "Event K-II (units 3-5, ca $130 \mathrm{ka}$ )"]. Unit D at Kongsøya may belong to the same event, but it is poorly dated [7] (Fig. 20).

Event L-VI is represented only by a thin unit of beach sediments (unit 18 , facies $\mathrm{D}$ ) dated to $36 \pm 3 \mathrm{ka}$ at Leinstranda. The only other site with raised marine sediments suggested to be of similar age is found at Isvika on Nordaustlandet (unit 6, 40-38 ka: Kaakinen et al. [16]) (Fig. 20), although other sites have sediments dated to this time within uncertainties (e.g. by radiocarbon).

\section{Summary and conclusions}

We have studied the upper $\sim 15 \mathrm{~m}$ of the coastal sections at Kongsfjordhallet in NW Svalbard, corresponding to succession A of Houmark-Nielsen and Funder [22]. Generally, our results support their interpretations, but we provide more detailed sedimentological facies interpretation and an improved chronological framework. The sediments at Kongsfjordhallet are dominated by marine and littoral deposits making up incomplete regression sequences that are important indicators both for glacial events, even when subglacial tills are lacking, and for establishing chronologic frameworks. We have suggested a facies model for such sequences which also includes the more rare terrestrial deposits (alluvial, periglacial) preserved here.
The sedimentary units at Kongsfjordhallet represent at least three, but most likely five high relative sea level events, which imply preceding regional glaciations. Together with the record from nearby Leinstranda $[10,28]$ we can thus identify six, possibly seven, major glacial advances during the last $200 \mathrm{ka}$. Two of these occurred during the Saalian and at least four during the Weichselian. The glaciations are constrained in time by the ages of the high relative sea-level events to just prior to $\sim 190, \sim 130, \sim 100-85 \mathrm{ka}$ (possibly two events), $\sim 60, \sim 35$, and $\sim 15 \mathrm{ka}$.

Correlation with sites elsewhere in Svalbard show that the early- and mid-Weichselian high sea-level events and corresponding glaciations are relatively poorly constrained. This is mainly because of the wide, in some places overlapping age spans for individual events that make it difficult to correlate between sites. The chronology for these events is largely or solely based on luminescence dating, which typically has age uncertainties of $\pm 5-10 \%$ [92]. The wide age ranges may be due to poor precision of single ages (commonly related to the luminescence characteristics of the dated mineral) or to a large spread of ages within a certain sedimentary unit (e.g. due to incomplete bleaching). Careful selection of sampled sediments along with adapted analysis of the sample may help to improve the situation.

Nonetheless, the number of events recognised in stratigraphic superposition at Kongsfjordhallet, along with additional events at other sites, suggests that the Svalbard-Barents sea ice sheet must have been very dynamic during the last $200 \mathrm{ka}$. The events showing regressional sequences cannot just represent ice margin oscillations but major advance/ retreat of the ice sheet that allows the earth's crust and mantle time to adapt isostatically. At Kongsfjordhallet, this is the case for all events except event K-IV, which does not have a shallowing-upward signal.

Our study encompasses only the uppermost of three successions at Kongsfjordhallet [22], and there is an additional $20 \mathrm{~m}$ of sediments below our unit 1, which is promising for future studies and makes Kongsfjordhallet a key stratigraphic site where multiple events are recorded in superposition.

Acknowledgements We very much appreciate the field assistance from and discussions with teachers (particularly Ólafur Ingólfsson) and students of the University Centre in Svalbard (UNIS) course AG332/832 in 2007-2015, as well as from Leif V. Jakobsen (Norwegian University of Life Sciences, NMBU) and Mikael Lindqvist and Jonas Svensson (Stockholm University). Logistic support from the Norwegian Polar Institute, particularly Wojciech Moskal, in Ny-Ålesund, and from UNIS made the field work easier. Anatoly Molodkov at the Tallinn University of Technology carried out the ESR dating and discussed the results. Andrew Murray and staff at the Nordic Laboratory for Luminescence dating welcomed Alexanderson and Ryen to do sample preparation and measurements, and aided initial analyses. Anne Karin Hufthammer (University of Bergen) identified the seal bone. Ólafur Ingólfsson and Wesley Farnsworth (UNIS) constructively commented on the manuscript. Reviews by Eiliv Larsen and an anonymous reviewer 
improved the manuscript. Most of this work was done as a part of the Norwegian Research Council-funded IPY SciencePub Project no. $175937 /$ S30, with additional funding from Svalbard Science Forum to Alexanderson and Ryen and from the Norwegian University of Life Sciences to Henriksen and Landvik.

\section{Compliance with ethical standards}

Conflict of interest On behalf of all authors, the corresponding author states that there is no conflict of interest.

Open Access This article is distributed under the terms of the Creative Commons Attribution 4.0 International License (http://creativeco mmons.org/licenses/by/4.0/), which permits unrestricted use, distribution, and reproduction in any medium, provided you give appropriate credit to the original author(s) and the source, provide a link to the Creative Commons license, and indicate if changes were made.

\section{References}

1. Hormes A, Gjermundsen EF, Rasmussen TL (2013) From mountain top to the deep sea - deglaciation in 4D of the northwestern Barents Sea. Quatern Sci Rev 75:78-99. https://doi.org/10.1016/j. quascirev.2013.04.009

2. Landvik JY, Alexanderson H, Henriksen M, Ingólfsson Ó (2014) Landscape imprints of changing glacial regimes during ice sheet build-up and decay: a conceptual model from Svalbard. Quater Sci Rev 92:258-268. https://doi.org/10.1016/j.quascirev.2013.11.023

3. Landvik JY, Bondevik S, Elverhøi A, Fjeldskaar W, Mangerud J, Salvigsen O, Siegert MJ, Svendsen J-I, Vorren TO (1998) The last glacial maximum of Svalbard and the Barents Sea area: ice sheet extent and configuration. Quatern Sci Rev 17:43-75

4. Ingólfsson Ó (2011) Fingerprints of Quaternary glaciations on Svalbard Geological Society. Lond Spec Publ 354:15-31. https:// doi.org/10.1144/sp354.2

5. Ingólfsson Ó, Landvik JY (2013) The Svalbard-Barents Sea icesheet-Historical, current and future perspectives. Quatern Sci Rev 64:33-60. https://doi.org/10.1016/j.quascirev.2012.11.034

6. Mangerud J, Dokken T, Hebbeln D, Heggen B, Ingólfsson Ó, Landvik JY, Mejdahl V, Svendsen JI, Vorren TO (1998) Fluctuations of the Svalbard-Barents Sea ice sheet during the last 150000 years. Quatern Sci Rev 17:11-42

7. Ingólfsson $\mathrm{O}$, Rögnvaldsson $\mathrm{F}$, Bergsten $\mathrm{H}$, Hedenäs L, Lemdahl G, Lirio JM, Sejrup HP (1995) Late Quaternary glacial and environmental history of Kongsøya, Svalbard. Polar Res 14:123-139

8. Mangerud J, Svendsen JI (1992) The last interglacial-glacial period on Spitsbergen, Svalbard. Quater Sci Rev 11:633-664

9. Miller GH (1982) Quaternary depositional episodes, western Spitsbergen, Norway: aminostratigraphy and glacial history. Arct Alp Res 14:321-340

10. Alexanderson H, Landvik JY, Ryen HT (2011) Chronology and styles of glaciation in an inter-fjord setting, northwest Svalbard. Boreas 40:175-197. https://doi.org/10.111 1/j.1502-3885.2010.00175.x

11. Miller GH, Sejrup HP, Lehman SJ, Forman SL (1989) Glacial history and marine environmental change during the last interglacialglacial cycle, western Spitsbergen, Svalbard. Boreas 18:273-296

12. Waelbroeck C, Labeyrie L, Michel E, Duplessy JC, McManus JF, Lambeck K, Balbon E, Labracherie M (2002) Sea-level and deep water temperature changes derived from benthic foraminifera isotopic records. Quatern Sci Rev 21:295-305
13. Alexanderson H, Backman J, Cronin TM, Funder S, Ingólfsson Ó, Jakobsson M, Landvik JY, Löwemark L, Mangerud J, März C, Möller P, O’Regan M, Spielhagen RF (2014) An Arctic perspective on dating Mid-Late Pleistocene environmental history. Quater Sci Rev 92:9-31. https://doi.org/10.1016/j.quasc irev.2013.09.023

14. Alexanderson H, Ingólfsson Ó, Murray AS, Dudek J (2013) An interglacial polar bear and an early Weichselian glaciation at Poolepynten, western Svalbard. Boreas 42:532-543. https://doi. org/10.1111/j.1502-3885.2012.00289.x

15. Eccleshall SV, Hormes A, Hovland A, Preusser F (2016) Constraining the chronology of Pleistocene glaciations on Svalbard: Kapp Ekholm re-visited. Boreas 45:790-803. https://doi. org/10.1111/bor.12191

16. Kaakinen A, Salonen V-P, Kubischta F, Eskola KO, Oinonen M (2009) Weichselian glacial stage in Murchisonfjorden, Nordaustlandet, Svalbard. Boreas 38:718-729

17. Ohta Y, Piepjohn K, Dallmann W, Elvevold S (2008) Geological map of Svalbard 1: 100,000, sheet A6G Krossfjorden Norsk Polarinstitutt. Temakart 42

18. Peterson G (2008) The development and relative chronology of landforms at Kongsfjordhallet, Spitsbergen. Bachelor thesis, Stockholm University

19. Henriksen M, Alexanderson H, Landvik JY, Linge H, Peterson G (2014) Dynamics and retreat of the Late Weichselian Kongsfjorden ice stream, NW Svalbard. Quater Sci Rev 92:235-245. https://doi.org/10.1016/j.quascirev.2013.10.035

20. Lehman SJ, Forman SL (1992) Late Weichselian glacier retreat in Kongsfjorden, west Spitsbergen, Svalbard. Quat Res 37:139-154

21. Boulton GS (1979) Glacial history of the Spitsbergen archipelago and the problem of a Barents Shelf Ice Sheet. Boreas 8:31-57

22. Houmark-Nielsen M, Funder S (1999) Pleistocene stratigraphy of Kongsfjordhallet, Spitsbergen, Svalbard. Polar Res 18:39-49

23. NPI (2014) Terrengmodell Svalbard (S0 Terrengmodell): Delmodell 5 m 2009_13822. Norwegian Polar Institute

24. Forman SL, Mann DH, Miller GH (1987) Late Weichselian and Holocene relative sea-level history of Bröggerhalvöya, Spitsbergen. Quater Res 27:41-50

25. Landvik JY, Brook EJ, Gualtieri L, Linge H, Raisbeck G, Salvigsen O, Yiou F (2013) ${ }^{10} \mathrm{Be}$ exposure age constraints on the Late Weichselian ice-sheet geometry and dynamics in inter-ice-stream areas, western Svalbard. Boreas 42:43-56. https://doi.org/10.111 1/j.1502-3885.2012.00282.x

26. Landvik JY, Ingólfsson Ó, Mienert J, Lehman SJ, Solheim A, Elverhøi A, Ottesen D (2005) Rethinking Late Weichselian icesheet dynamics in coastal NW Svalbard. Boreas 34:7-24

27. Ottesen D, Dowdeswell JA, Landvik JY, Mienert J (2007) Dynamics of the Late Weichselian ice sheet on Svalbard inferred from high-resolution sea-floor morphology. Boreas 36:286-306

28. Alexanderson H, Landvik JY, Molodkov A, Murray AS (2011) A multi-method approach to dating middle and late Quaternary high relative sea-level events on NW Svalbard-a case study. Quat Geochronol 6:326-340. https://doi.org/10.1016/j.quage o.2011.04.001

29. Andersen ES, Dokken TM, Elverhøi A, Solheim A, Fossen I (1996) Late Quaternary sedimentation and glacial history of the western Svalbard continental margin. Mar Geol 133:123-156. https://doi.org/10.1016/0025-3227(96)00022-9

30. Vorren TO, Laberg JS, Blaume F, Dowdeswell JA, Kenyon NH, Mienert J, Rumohr J, Werner F (1998) The Norwegian-Greenland sea continental margins: morphology and late Quaternary sedimentary processes and environment. Quatern Sci Rev 17:273302. https://doi.org/10.1016/S0277-3791(97)00072-3

31. Hughes ALC, Gyllencreutz R, Lohne ØS, Mangerud J, Svendsen JI (2016) The last Eurasian ice sheets-a chronological database 
and time-slice reconstruction, DATED-1. Boreas 45:1-45 https ://doi.org/10.1111/bor.12142

32. Jessen SP, Rasmussen TL, Nielsen T, Solheim A (2010) A new Late Weichselian and Holocene marine chronology for the western Svalbard slope 30,000-0 cal years BP. Quatern Sci Rev 29:1301-1312

33. Howe JA, Moreton SG, Morri C, Morris P (2003) Multibeam bathymetry and the depositional environments of Kongsfjorden and Krossfjorden, western Spitsbergen, Svalbard. Polar Res 22:301-316. https://doi.org/10.1111/j.1751-8369.2003.tb001 14.x

34. Grant OR (2016) The deglaciation of Kongsfjorden, Svalbardbased on surface exposure dating of glacial erratics and Quaternary geological mapping of Blomstrandhalvøya. MSc thesis, University of Bergen

35. Krumbein WC (1941) Measurement and geological significance of shape and roundness of sedimentary particles. J Sediment Res 11:64-72

36. Powers MC (1953) A new roundness scale for sedimentary particles. J Sediment Res 23:117-119

37. Banerjee D, Murray AS, Bøtter-Jensen L, Lang A (2001) Equivalent dose estimation using a single aliquot of polymineral fine grains. Radiat Meas 33:73-94

38. Murray AS, Marten R, Johnson A, Martin P (1987) Analysis for naturally occurring radionuclides at environmental concentrations by gamma spectrometry. J Radioanal Nucl Chem Art 115:263288. https://doi.org/10.1007/BF02037443

39. Prescott JR, Hutton JT (1994) Cosmic ray contributions to dose rates for luminescence and ESR dating: large depths and longterm time variations. Radiat Meas 23:497-500. https://doi. org/10.1016/0277-3791(95)00037-2

40. Pusch R (1973) Densitet, vattenhalt och portal. Byggforskningens informationsblad 5:27

41. Wintle AG, Murray AS (2006) A review of quartz optically stimulated luminescence characteristics and their relevance in singlealiquot regeneration dating protocols. Radiat Meas 41:369-391

42. Lowick SE, Buechi MW, Gaar D, Graf HR, Preusser F (2015) Luminescence dating of Middle Pleistocene proglacial deposits from northern Switzerland: methodological aspects and stratigraphical conclusions. Boreas 44:459-482. https://doi. org/10.1111/bor.12114

43. Molodkov A (1988) ESR dating of Quaternary shells: recent advances. Quatern Sci Rev 7:477-484

44. Molodkov A (1993) ESR-dating of non-marine mollusc shells. Appl Radiat Isot 43:145-148. https://doi.org/10.1016/09698043(93)90209-S

45. Bronk Ramsey C (2009) Bayesian analysis of radiocarbon dates. Radiocarbon 51:337-360

46. Reimer PJ, Bard E, Bayliss A, Beck JW, Blackwell PG, Bronk Ramsey C, Buck CE, Cheng H, Edwards RL, Friedrich M, Grootes PM, Guilderson TP, Haflidason H, Hajdas I, Hatté C, Heaton TJ, Hoffmann DL, Hogg AG, Hughen KA, Kaiser KF, Kromer B, Manning SW, Niu M, Reimer RW, Richards DA, Scott EM, Southon JR, Staff RA, Turney CSM, van der Plicht J (2013) IntCal13 and Marine13 radiocarbon age calibration curves 0-50,000 years cal. BP Radiocarbon 55:1869-1887. https://doi. org/10.2458/azu_js_rc.55.16947

47. Mangerud J, Bondevik S, Gulliksen S, Hufthammer AK, Høisæter $\mathrm{T}$ (2006) Marine ${ }^{14} \mathrm{C}$ reservoir ages for 19th century whales and molluscs from the North Atlantic. Quatern Sci Rev 25:3228-3245

48. Benn DI, Evans DJA (2010) Glaciers \& glaciation, 2nd edn. Hodder Education, London

49. Domack EW, Lawson DE (1985) Pebble fabric in an ice-rafted diamicton. J Geol 93:577-591. https://doi.org/10.1086/628982
50. Mulder T, Alexander J (2001) The physical character of subaqueous sedimentary density flows and their deposits. Sedimentology 48:269-299

51. Lowe DR (1982) Sediment gravity flows; II, Depositional models with special reference to the deposits of high-density turbidity currents. J Sediment Res 52:279-297. https://doi.org/10.1306/212f7 f31-2b24-11d7-8648000102c1865d

52. Thomas GSP, Connell RJ (1985) Iceberg drop, dump, and grounding structures from Pleistocene glaciolacustrine sediments, Scotland. J Sediment Petrol 55:243-249

53. Evans DJA, Phillips ER, Hiemstra JF, Auton CA (2006) Subglacial till: formation, sedimentary characteristics and classification. Earth Sci Rev 78:115-176

54. Krüger J (1984) Clasts with stoss-lee form in lodgement tills: a discussion. J Glaciol 30:241-243

55. Sharp M (1982) Modification of clasts in lodgement tills by glacial erosion. J Glaciol 28:475-481

56. Dallmann WK (ed) (2015) Geoscience atlas of Svalbard, vol 148. Norwegian Polar Institute, Troms $\varnothing$ Norwegian Polar Institute Report

57. Powell RD (1984) Glacimarine processes and inductive lithofacies modelling of ice shelf and tidewater glacier sediments based on Quaternary examples. Mar Geol 57:1-52. https://doi. org/10.1016/0025-3227(84)90194-4

58. Massari F, Parea GC (1988) Progradational gravel beach sequences in a moderate- to high-energy microtidal marine environment. Sedimentology 35:881-913

59. Forman SL, Miller GH (1984) Time-dependent soil morphologies and pedogenic processes on raised beaches, Bröggerhalvöya, Spitsbergen, Svalbard archipelago. Arct Alp Res 16:381-394

60. Matsuoka N (1990) Mechanisms of rock breakdown by frost action: An experimental approach. Cold Reg Sci Technol 17:253270. https://doi.org/10.1016/S0165-232X(05)80005-9

61. French HM (1996) The periglacial environment. Longman, Harlow

62. Johnsson G (1962) Periglacial phenomena in Southern Sweden: I. Stratigraphy. Geografiska Annaler 44:378-404. https://doi. org/10.2307/520321

63. Landvik JY, Bolstad M, Lycke AK, Mangerud J, Sejrup HP (1992) Weichselian stratigraphy and palaeoenvironments at Bellsund, western Svalbard. Boreas 21:335-358

64. Postma G, Nemec W (1990) Regressive and transgressive sequences in a raised Holocene gravelly beach, southwestern Crete. Sedimentology 37:907-920. https://doi. org/10.1111/j.1365-3091.1990.tb01833.x

65. van Vliet-Lanoe B (1993) Solifluction activity in the North Atlantic arctic and sub-arctic: the microstratigraphic record of changing climate during the second half of the Holocene. In: Frenzel B (ed) Solifluction and Climatic Variation in the Holocene. Palaeoclimate Research, vol 11. Gustav Fischer Verlag, Stuttgart, pp 279-294

66. Forman SL, Lubinski DJ, Ingólfsson Ó, Zeeberg JJ, Snyder JA, Siegert MJ, Matishov GG (2004) A review of postglacial emergence on Svalbard, Franz Josef Land and Novaya Zemlya, northern Eurasia. Quatern Sci Rev 23:1391-1434

67. Harris C, Kern-Luetschg M, Christiansen HH, Smith F (2011) The role of interannual climate variability in controlling solifluction processes, Endalen, Svalbard. Permafr Periglac Process 22:239-253. https://doi.org/10.1002/ppp.727

68. Åkerman HJ (1993) Solifluction and creep rates 1972-1991, Kapp Linne, West Spitsbergen. In: Frenzel B (ed) Solifluction and climatic variation in the Holocene. Palaeoclimate research, vol 11. Gustav Fischer Verlag, Stuttgart, pp 225-249

69. Andersson T, Forman SL, Ingólfsson Ó, Manley WF (1999) Late Quaternary environmental history of central Prins Karls Forland, western Svalbard. Boreas 28:292-307 
70. Andersson T, Forman SL, Ingólfsson Ó, Manley WF (2000) Stratigraphic and morphologic constraints on the Weichselian glacial history of northern Prins Karls Forland, western Svalbard. Geografiska Annaler 82A:455-470

71. Farnsworth WR, Ingólfsson Ó, Noormets R, Allaart L, Alexanderson H, Henriksen M, Schomacker A (2017) Dynamic Holocene glacial history of St. Jonsfjorden, Svalbard. Boreas 46:585-603. https://doi.org/10.1111/bor.12269

72. Lønne I (2005) Faint traces of high Arctic glaciations: an early Holocene ice-front fluctuation in Bolterdalen, Svalbard. Boreas 34:308-323. https://doi.org/10.1111/j.1502-3885.2005.tb01103.x

73. Möller P, Lubinski DJ, Ingólfsson O, Forman SL, Seidenkrantz M-S, Bolshiyanov DY, Lokrantz H, Antonov O, Pavlov M, Ljung K, Zeeberg J, Andreev A (2006) Severnaya Zemlya, Arctic Russia: a nucleation area for Kara Sea ice sheets during the Middle to Late Quaternary. Quatern Sci Rev 25:2894-2936. https://doi. org/10.1016/j.quascirev.2006.02.016

74. Bergsten H, Andersson T, Ingólfsson Ó (1998) Foraminiferal stratigraphy of raised marine deposits, representing isotope stage 5, Prins Karls Forland, western Svalbard. Polar Res 17:81-91. https ://doi.org/10.1111/j.1751-8369.1998.tb00261.x

75. Lønne I, Nemec W (2004) High-arctic fan delta recording deglaciation and environment disequilibrium. Sedimentology 51:553-589

76. Landvik JY, Salvigsen O (1985) Glaciation development and interstadial sea-level on central Spitsbergen, Svalbard. Polar Res 3:1-10. https://doi.org/10.1111/j.1751-8369.1985.tb00491.x

77. Lagerbäck R (1988) Periglacial phenomena in the wooded areas of Northern Sweden - relicts from the Tärendö Interstadial. Boreas 17:487-499. https://doi.org/10.1111/j.1502-3885.1988.tb00563.x

78. Francou B (1990) Stratification mechanisms in slope deposits in high subequatorial mountains. Permafrost Periglac Process 1:249-263

79. Bertran P, Texier J-P (1999) Facies and microfacies of slope deposits. CATENA 35:99-121. https://doi.org/10.1016/S0341 -8162(98)00096-4

80. Mann DH, Sletten RS, Ugolini FC (1986) Soil development at Kongsfjorden, Spitsbergen. Polar Res 4:1-16

81. Munroe JS, Bockheim JG (2001) Soil development in low-arctic tundra of the Northern Brooks Range, Alaska, USA. Arctic Antarct Alp Res 33:78-87

82. Courty MA, Marlin C, Dever L, Tremblay P, Vachier P (1994) The properties, genesis and environmental significance of calcitic pendents from the High Arctic (Spitsbergen). Geoderma 61:71102. https://doi.org/10.1016/0016-7061(94)90012-4

83. Alexanderson H, Murray AS (2012) Luminescence signals from modern sediments in a glaciated bay, NW Svalbard. Quater Geochronol 10:250-256. https://doi.org/10.1016/j.quage o.2012.01.001

84. Chauhan T, Rasmussen TL, Noormets R (2016) Palaeoceanography of the Barents Sea continental margin, north of Nordaustlandet, Svalbard, during the last $74 \mathrm{ka}$. Boreas 45:76-99. https://doi. org/10.1111/bor.12135

85. Forman SL (1999) Infrared and red stimulated luminescence dating of Late Quaternary near-shore sediments from Spitsbergen, Svalbard. Arctic Antarct Alpine Res 31:34-49

86. Das VK (2016) Palaeoenvironmental reconstructions of the Late Pleistocene deposits of (northwestern) Spitsbergen, Svalbard-constraints from benthic foraminiferal records. MSc thesis, Jadavpur University

87. Das VK, Ghosh A, Alexanderson H, Henriksen M, Landvik JY, Ryen HT (2015) Paleoenvironmental reconstructions of the late Pleistocene deposits of Kongsfjorden in the Svalbard region based on a multi-proxy approach. Paper presented at the 2015 INQUA Congress, Nagoya, Japan, 26 July-2 August 2015

88. Alexanderson H, Landvik JY (submitted) New OSL ages from Skilvika, SW Svalbard confirm sediments of MIS 5 age. Polar Res

89. Mangerud J, Bolstad M, Elgersma A, Helliksen D, Landvik JY, Lønne I, Lycke AK, Salvigsen O, Sandahl T, Svendsen JI (1992) The last glacial maximum on Spitsbergen, Svalbard. Quater Res 38:1-31

90. Lønne I, Mangerud J (1991) An early or middle Weichselian sequence of proglacial shallow marine sediments on western Svalbard. Boreas 20:85-104. https://doi. org/10.1111/j.1502-3885.1991.tb00298.x

91. Landvik JY, Brook EJ, Gualtieri L, Raisbeck G, Salvigsen O, Yiou F (2003) Northwest Svalbard during the last glaciation: Ice-free areas existed. Geology 31:905-908. https://doi.org/10.1130/g1970 3.1

92. Rhodes EJ (2011) Optically stimulated luminescence dating of sediments over the past 200,000 years. Ann Rev Earth Planet Sci 39:461-488. https://doi.org/10.1146/annurev-earth-040610-13342 5 